\title{
DEBT SUSTAINABILITY AND FISCAL
}

SPACE IN A HETEROGENEOUS

2020 MONETARY UNION: NORMAL TIMES VS THE ZERO LOWER BOUND

\section{BANCODEESPAÑA}

Documentos de Trabajo

N. ${ }^{\circ} 2001$

Javier Andrés, Pablo Burriel and Wenyi Shen 
DEBT SUSTAINABILITY AND FISCAL SPACE IN A HETEROGENEOUS

MONETARY UNION: NORMAL TIMES VS THE ZERO LOWER BOUND 
DEBT SUSTAINABILITY AND FISCAL SPACE

IN A HETEROGENEOUS MONETARY UNION:

NORMAL TIMES VS THE ZERO LOWER BOUND ${ }^{(*)}$

Javier Andrés ${ }^{(*)}$

UNIVERSIDAD DE VALENCIA

Pablo Burriel ${ }^{(* * *)}$

BANCO DE ESPAÑA

Wenyi Shen ${ }^{(* * *)}$

OKLAHOMA STATE UNIVERSITY

$\left(^{*}\right)$ We thank Dennis Bonam, seminar participants at the Banco de España, the 21st Bank of Italy Workshop on Public Finance, the Fiscal Policy Seminar 2018 at the Federal Ministry of Finance in Berlin, the 2019 Computing in Economics and Finance Conference and an anonimous referee for their comments and suggestions. Javier Andrés acknowledges the financial support by the Spanish Ministry of Economy and Competitiveness (grant ECO2017-84632-R) and Generalitat Valenciana (Conselleria d'Educació, Investigació, Cultura i Esports, grant GVPROMETEO2016-097).

$\left.{ }^{* *}\right)$ Andrés: Departamento de Análisis Económico, Universidad de Valencia, Valencia, Spain, javier.andres@uv.es. $\left.{ }^{(\star \star}\right)$ Burriel: Fiscal Policy Unit, DG Economics and Statistics, Banco de España, Madrid, Spain, pburriel@bde.es. $\left(^{\star \star \star \star}\right)$ Shen: Department of Economics, Oklahoma State University, Stillwater, OK 74078, wenyi.shen@okstate.edu. 
The Working Paper Series seeks to disseminate original research in economics and finance. All papers have been anonymously refereed. By publishing these papers, the Banco de España aims to contribute to economic analysis and, in particular, to knowledge of the Spanish economy and its international environment.

The opinions and analyses in the Working Paper Series are the responsibility of the authors and, therefore, do not necessarily coincide with those of the Banco de España or the Eurosystem.

The Banco de España disseminates its main reports and most of its publications via the Internet at the following website: http://www.bde.es.

Reproduction for educational and non-commercial purposes is permitted provided that the source is acknowledged.

(C) BANCO DE ESPAÑA, Madrid, 2020

ISSN: 1579-8666 (on line) 
In this paper we study fiscal policy effects and fiscal space for countries in a monetary union with different levels of public debt. We develop a dynamic stochastic general equilibrium (DSGE) model of a two-country monetary union, calibrated to match the characteristics of Spain and Germany, in which debt sustainability is endogenously determined a la Bi (2012) to shape the responses of the risk premium on public debt. Policy shocks change the market's expectation about future primary surplus, producing a direct effect on the sovereign risk premium and macroeconomic responses of the economy. In normal times the costs of a government spending driven fiscal consolidation in the high-debt country are greatly diminished when this consolidation improves endogenously its debt sustainability prospects. Fiscal consolidations in both members of the monetary union decrease real interest rates and amplify the reduction in risk premium in the highly-indebted country, improving union-wide output in the long run, but at the cost of lower output in the lowdebt country in the short term. On the contrary, when monetary policy is constrained at the zero lower bound, the risk premium channel arising from the endogenous determination of debt sustainability becomes muted. In the ZLB, a fiscal consolidation generates deflation expectations which increase the real interest rate and may compensate partially or completely, depending on the calibration, the benefits from a lower risk premium. In this context, a fiscal expansion in the low-debt country and a consolidation in the highdebt country delivers the greater positive impact on union-wide output. Finally, the risk premium channel only affects countries with medium or low levels of public debt indirectly through the negative spillovers from other high-debt members of the monetary union.

Keywords: fiscal sustainability, sovereign debt default risk, monetary union.

JEL classification: E31, E62, H30. 
En este documento se estudian los efectos de la política fiscal y el espacio fiscal existente en una unión monetaria compuesta por países con distintos niveles de deuda pública. Desarrollamos un modelo de equilibrio general dinámico y estocástico (DSGE, por sus siglas en inglés) de una unión monetaria de dos países, calibrada a partir de las características de España y Alemania, en el que la sostenibilidad de la deuda pública y su prima de riesgo se determinan de forma endógena según el mecanismo propuesto por $\mathrm{Bi}$ (2012). En este modelo, las decisiones de política económica modifican las expectativas de los mercados sobre los superávits futuros afectando directamente a la prima de riesgo soberana y a las respuestas de las principales variables macroeconómicas. En tiempos normales, el coste de una consolidación fiscal basada en una reducción del gasto público en un país miembro de la unión con deuda elevada se ve reducido cuando esta mejora las perspectivas de sostenibilidad de su deuda pública. Una consolidación fiscal simultánea en los dos miembros de la unión reduce aún más los tipos de interés reales, lo que amplifica la caída de la prima de riesgo en el país más endeudado y, pese a reducir la actividad económica del conjunto de la unión en el corto plazo, puede suponer una mejora en el largo plazo. Por el contrario, cuando la política monetaria está restringida por haber alcanzado los tipos de interés nominales su cota inferior (ZLB, por sus siglas en inglés), el canal de la prima de riesgo ve muy reducida su efectividad. En esta situación, una consolidación fiscal genera expectativas deflacionarias que aumentan el tipo de interés real, lo que puede compensar total o parcialmente, según la calibración, los beneficios derivados de la menor prima de riesgo. Así, la estrategia que proporcionaría un mayor aumento de la actividad en el conjunto de la unión en el ZLB sería una expansión fiscal en el país menos endeudado y una consolidación en el más endeudado. Finalmente, el canal de prima de riesgo solo afecta de forma indirecta a los miembros de la unión monetaria con un nivel de deuda medio o bajo, a través de los efectos sobre la economía de los miembros con una deuda elevada.

Palabras clave: sostenibilidad fiscal, prima de riesgo soberano, unión monetaria.

Códigos JEL: E31, E62, H30. 


\section{Introduction}

The global financial and economic crisis left a legacy of historically high levels of public debt in advanced economies, at a scale unseen during modern peace time. Keeping public debt at high levels, however, is a source of vulnerability in itself, particularly given the arising fiscal and economic pressures from ageing. A high public debt burden is even more problematic in a monetary union like the euro area (EA), as monetary policy focuses on the EA aggregate while fiscal policy decisions remain at the national level. As shown in Figure 1, although the average debt to GDP ratio in the EA stays high at 90 percent, a great dispersion exists across countries. In fact countries with reasonably low debt levels by the end of 2018, standing at around or below 60 percent, including Germany (61 percent) and The Netherlands (52 percent), coexist with others characterized by high debt levels, around or above 100 percent of GDP, including France (98 percent), Italy (132 percent) and Spain (97 percent). In those highly indebted countries, borrowing costs have increased sharply, which undermine their solvency, all the more if they have to face a severe slowdown in economic growth in the near future. Moreover, risks to debt sustainability in a highdebt large Member State, like the ones recently experienced in Italy, can entail risks to the stabilization of the monetary union as a whole, while cross-country spillovers of disorderly default can threaten the very existence of the EA.

Despite the difficult financial position in some countries, the debate on fiscal strategies is far from settled in the Euro area. The mandate to reduce public deficits and debt is the official policy although there is some disagreement about the timing of that process. Also the weakening of the recovery phase has stirred up some fears that unconventional monetary stimuli might be losing steam and many voices have been raised in favor of a more expansionary fiscal stance, at least in the core countries of the EMU in which sustainability issues are less pressing. But also, more recently, the IMF (WEO 2019) suggested that in case of a further weakening in growth, high-debt countries could temporarily slow down their fiscal consolidation efforts, provided the financial markets permit this and debt sustainability is not put at risk. Much of the support for this fiscal expansion relies on the idea that the safe interest rate is expected to be below the nominal growth rate in the near (and even in the distant) future, so that "public debt may have no cost" (Blanchard (2019)) However, if the interest rate carries a risk premium and if this is affected not only by the actions in the country with high debt but also by what other countries in the monetary union do, the case in favor of fiscal activism ought to be revisited. If that is the case the cost of debt might be significant and fiscal multipliers smaller, making fiscal consolidation more appealing, depending on the prevailing monetary conditions in the union. 
Figure 1: Evolution of government debt and spreads in the euro area

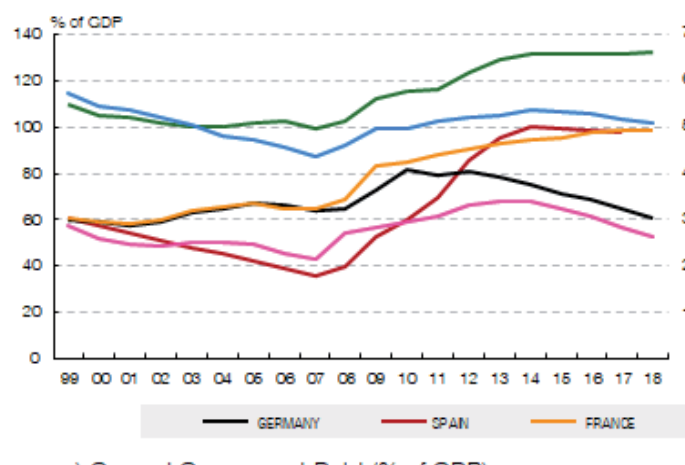

a) General Government Debt (\% of GDP)

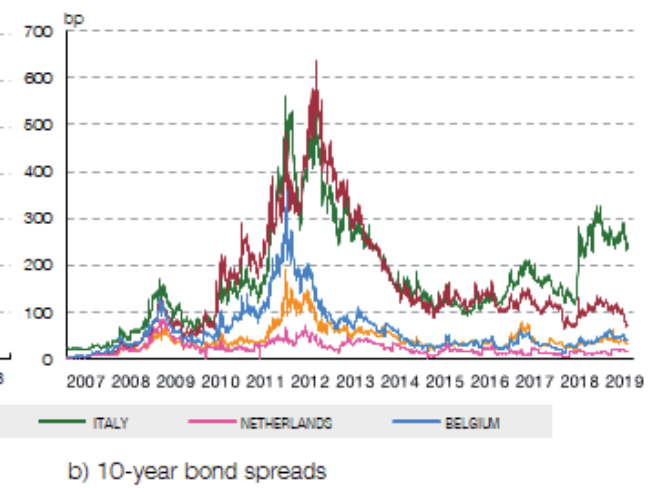

b) 10-year bond spreads

In this paper we assess the effect of alternative fiscal policy actions in a monetary union in which individual country members differ in the risk of sustainability of their public finances. Countries with low and high public debt to GDP ratios coexist (where high and low will be defined more precisely later on) and the fiscal actions can be either coordinated or unilateral and may happen in normal monetary policy times or when the area wide monetary authority is constrained by the lower bound of the interest rate. We pay special attention to the crosscountry spillovers of fiscal polices in this setup.

We extend a standard dynamic stochastic general equilibrium (DSGE) model of a twocountry monetary union along the lines of Benigno and Benigno (2006), modified to allow for debt sustainability to be endogenously determined. In particular, (partial) government default may occur, so that a haircut is applied whenever the debt of one of the country members of the monetary union becomes unsustainable. In the model debt sustainability is operationalized through the use of the concept of "fiscal limit" along the lines defined by Bi (2012). In particular, the fiscal limit is the maximum amount of public debt relative to GDP that the government can finance without defaulting on their financial commitments, and is calculated as the expected discounted sum of maximum primary surplus that can be generated in the future, given the current fiscal strategy and the expected evolution of the economy. Given exogenous fluctuations in fiscal policy shocks and political risk, this fiscal limit is stochastic. Therefore, investors may demand risk premia on government debt when the probability of hitting the fiscal limit increases beyond some level, even if the fiscal limit itself has not been reached. This generates a nonlinear relationship between sovereign risk premia and the level of government debt. As the high-debt (home) country approaches its fiscal limit, it pays a higher default risk premium on its public debt. The low-debt (foreign) country, however, is far away from its fiscal limit and hence pays the risk free rate.

The simulated fiscal limit, which we refer as "state-dependent fiscal limit" is dynamic, and a function of the state of both the home and foreign economies, and the political constraints 
on revenue collection capacity. Policy decisions affect the fiscal limit distribution and the sovereign risk premium. The endogeneity of the fiscal limit gives rise to a powerful sovereign risk premium channel and thus to cross-country spillovers (fiscal or otherwise) in the monetary union. These spillovers are asymmetric, inducing quite different macroeconomic responses in the country with high debt as compared with an economy operating well away from its fiscal limit.

In this paper, a government's default on its debt is the result of an accident, modelled as a random draw from the fiscal limit distribution, rather than a strategic decision. The reason for this is that a member of a monetary union like the euro area cannot strategically default on its debt without leaving the union, since this would immediately stop the access of its domestic banks to the union central bank's financing with the subsequent bank run. Instead, the most realistic situation is, as the case of Greece in the sovereign crisis illustrated, that if a sequence of negative (random) economic or political shocks make the government's debt of a member unsustainable, in the sense that it is in a trajectory that will eventually not be financiable, then it has to enter into a program and an agreement to restructure its debt is implemented. Therefore, the role of the government in our model is limited to setting distortionary taxes in line with the fiscal rule.

Against this backdrop, we analyze three timely fiscal issues in the European policy debate: the long-run consolidation process a high-debt country must endure to converge back towards more sustainable debt levels, the impact of short-run discretionary fiscal policy in countries with strained public finances, and the effect of fiscal policy coordination between the highdebt and low-debt countries. In the absence of lump-sum taxes, adjusting to lower levels of public debt is always a costly and lengthy process. However, we find that under normal monetary conditions a discretionary consolidation effort that speeds up such process in the high-debt country, might help in moderating that cost as long as it helps to take the debt to GDP ratio away from the risky zone (the proximity of the fiscal limit). A fiscal consolidation today implies higher future primary surpluses, shifting the fiscal limit distribution to the right and reducing the probability of default on impact. This effect on the risk premium is small but persistent in time, inducing sizeable output effects. In our simulations, a 1 percent transitory reduction in government spending reduces the risk premium on impact by 1.5 basis points (bp), reaching a maximum of 4 bp after 5 years, and it is still 2 bp lower after 10 years. The lower financing costs significantly reduce the cost of a transitory consolidation and generate a cumulative output multiplier of -0.49 after 10 years, suggesting expansionary fiscal consolidation, which would be consistent with the empirical findings in Giavazzi and Pagano (1990), Alesina et al. (1998), and Alesina and Ardagna (2010). We also analyze the spillover effects on a high debt country from the fiscal decisions of the low-debt country and 
fiscal policy coordination in the union. A fiscal expansion in the foreign (low-debt) country leads to inflation, and given its large size, increases the nominal interest rate in the Euro Area and real interest rates in both countries. The higher real rates lower demand in the home (high-debt) country and increase the cost of servicing the debt, thus worsening its fiscal sustainability prospects and rising the risk premium. As debt accumulates faster, high tax rates further depress output in the home country and reduce union output in the long run. Alternatively, a fiscal consolidation in the foreign country lowers real interest rates and improves home country's debt sustainability (shifts the fiscal limit to the right). Lower debt services increase home output and lead to long run output gain in the union, at a cost of short run output loss in the foreign country. Given these results, in normal times the best fiscal policy coordination in the union would be a joint consolidation, but this may not be feasible since it would contract activity in the low-debt country. Alternatively, the high-debt country consolidates and the low-debt country remains inactive.

When monetary policy is constrained at the zero lower bound (ZLB) these results do not hold. The real interest rate channel works against the risk premium channel arising from the state-dependent fiscal limit, making the response in risk premium muted. On the one hand, a discretionary fiscal consolidation at home improves future primary surplus and lowers the default probability. On the other hand, a fiscal consolidation generates deflation expectations that increase the real interest rate and the cost of rolling over debt, increasing the default probability. These two effects offset each other, but under our calibration the effect of the increase in real interest rates dominates the improvement in risk premium derived from the reduction in government spending, making fiscal consolidation counterproductive. The response of the fiscal limit to other fiscal measures at home or abroad is also very different in these circumstances (as compared with that in normal monetary conditions).

Our paper is related to several studies that connect sovereign risk premia and fiscal sustainability. Battistini et al. (2019) study fiscal and monetary policy interactions in a closed economy with an exogenous fiscal limit. Daniel and Shiamptanis (2012) assume government debt is constrained by an ad-hoc fiscal limit to assess fiscal crisis probabilities in the context of a monetary union. Polito and Wickens (2015) present a model-based measure of sovereign credit ratings for EU countries by estimating the probability that the debt to GDP ratio will exceed a given limit or threshold at any time over a given time horizon. Uribe and Yue (2006) and Garcia-Cicco et al. (2010) consider an exogenous risk premium by assuming that the sovereign risk premium is monotonically increasing in the level of government debt. In this same line, Corsetti et al. (2013) and Batini et al. (2018) propose a model where the euro area periphery government is faced with a fiscal limit following a beta distribution calibrated using data for Greece, which we call "exogenous fiscal limit". Our paper constructs model- 
consistent state-dependent fiscal limits that account for interactions among economic policy, changes in the environment or social attitudes towards taxes, and the sovereign risk premium. This method captures endogenous responses of fiscal limits to economic disturbances, which strengthen significantly the risk premium channel. In particular, we show that making the fiscal limit state-dependent reduces the government spending multiplier by 60 percent compared with what is obtained in the model with an exogenous fiscal limit.

Our analysis is also related to papers that study cross-border spillovers from fiscal stimulus, such as Corsetti et al. (2010), Arce et al. (2016), Blanchard et al. (2017) and Farhi and Werning (2016). These works find that fiscal adjustment instruments, structural reforms, and monetary policy all matter for the magnitude of fiscal spillovers in the Euro Area, but they do not incorporate default risk.

Finally, our paper is not meant to add to the theory of sovereign default, as in Eaton and Gersovitz (1981), Arellano (2008), Mendoza and Yue (2012) and Dovis (2019). These papers model the strategic sovereign default decision of an optimizing government that accounts for the economic costs in making default decisions. In this paper, as was mentioned above, rather than making the default decision a strategic choice, we opt to treat the intrinsically political decision as a random draw from the fiscal limit distribution. The reason for this modelling choice is twofold. First, in a monetary union like the euro area a strategically default on its debt would imply leaving the union. This very interesting research question is related to the reasons to form a currency union, as in Chari et al. (2019), but beyond the scope of this paper. Second, this way our model retains the DSGE framework convenient for incorporating several economic and policy shocks and conducting fiscal experiments without explicitly modeling the strategic default decision.

The paper is organized as follows. In the next section the baseline model is described, while section 3 details the model calibration. Section 4 explains how the model-consistent state-dependent fiscal limit is derived and how it is affected by macroeconomic fundamentals and policy decisions. In section 5 the main fiscal policy experiments are described. Finally, section 6 concludes.

\section{Model}

We use a two-country New Keynesian model to analyze a monetary union along the lines of Benigno and Benigno (2006), augmented with endogenously determined state-dependent fiscal limits and interest risk premia. Specifically, the monetary union consists of two countries, home and foreign, each inhabited by a continuum of households, with parameter $s$ determining the relative size of the home country. The foreign variables are defined with an 
asterisk. To incorporate sovereign default risk and capture different fiscal positions of union members, our model allows for the possibility of (partial) government default in the home country: a haircut is applied when the home country's level of debt becomes unsustainable. The concept of debt sustainability is operationalized by the "fiscal limit", which will be defined below. As debt approaches the fiscal limit, households in the home country may demand risk premia on government debt. We assume that the public debt to GDP ratio in the foreign country is sufficiently low so that, for simplicity, we assume there is no fiscal limit in this country that pays always the risk free rate. In the rest of the section we will describe the model for the home country and only mention the rest of the union when there is an asymmetry.

\subsection{Households}

The home country is populated by a large number of households indexed by $h \in[0, s)$, while those living in the foreign country are indexed by $f \in[s, 1]$. Preferences are given by:

$$
\max _{c_{t}, B_{t}, n_{t}} E_{t} \sum_{t=0}^{\infty} \beta^{t}\left[\frac{c_{t}^{1-\sigma}}{1-\sigma}-\frac{n_{t}^{1+\varphi}}{1+\varphi}\right]
$$

where $\beta$ is the households' subjective discount factor, $c_{t}$ is consumption and $n_{t}$ the households' labor supply. The inverse of intertemporal elasticity of substitution, $\sigma$, measures relative risk aversion. The parameter $\varphi$ governs the Frisch elasticity of labor supply. The household receives nominal wages $W_{t}$ and monopoly profits $\Upsilon_{t}$ from the firm, both of which are taxed at the rate $\tau_{t}$. The household maximizes utility subject to the budget constraint,

$$
P_{t} c_{t}+\frac{B_{t}}{R_{t}}+\frac{D_{t}}{R_{t}^{f}}=\left(1-\delta_{t}\right) B_{t-1}+D_{t-1}+\left(1-\tau_{t}\right)\left(W_{t} n_{t}+P_{H, t} \Upsilon_{t}\right)
$$

where $P_{t}$ is the CPI and $P_{H, t}$ is the PPI.

The government debt in the home country, $B_{t}$, is subject to default risk. The default decisions depend on a realized effective fiscal limit, $\mathcal{B}_{t}^{H}$, drawn from a fiscal limit distribution $\mathcal{B}^{H}\left(\mathcal{S}_{t}\right)$, conditional on the state $\mathcal{S}_{t}$. Specifically,

$$
\delta_{t}= \begin{cases}0 & \text { if } \quad b_{t-1}<\mathcal{B}^{H}\left(\mathcal{S}_{t}\right) \\ \delta & \text { if } \quad b_{t-1} \geq \mathcal{B}^{H}\left(\mathcal{S}_{t}\right)\end{cases}
$$

where $b_{t-1}=\frac{B_{t-1}}{P_{t}}$ is the real government debt. If the real value of debt at the beginning of period $t, b_{t-1}$, exceeds the effective fiscal limit, $\mathcal{B}_{t}^{H}$, then the government partially defaults 
and outstanding debt at the beginning of period $t$ becomes $(1-\delta) b_{t-1}$, otherwise it repays in full amount with $\delta_{t}=0$. The derivation of $\mathcal{B}^{H}\left(\mathcal{S}_{t}\right)$ is described in Section 4.1. Government debt in the home country, therefore, pays a risky yield of $R_{t}$. In addition, households may also hold a risk-free bond, $D_{t}$, that pays the risk-free rate $R_{t}^{f}$, with an aggregate zero net supply in each country.

Optimization conditions for households in the home country are:

$$
\begin{aligned}
n_{t}^{\varphi} & =\lambda_{t}\left(1-\tau_{t}\right) w_{t} \\
\lambda_{t} & =\beta R_{t} E_{t} \frac{\left(1-\delta_{t+1}\right) \lambda_{t+1}}{\pi_{t+1}} \\
\lambda_{t} & =\beta R_{t}^{f} E_{t} \frac{\lambda_{t+1}}{\pi_{t+1}}
\end{aligned}
$$

where $\lambda_{t}=c_{t}^{-\sigma}, \pi_{t+1}=\frac{P_{t+1}}{P_{t}}$, and $w_{t}=\frac{W_{t}}{P_{t}}$ is the real wage. The latter two equations determine the interest rate spread on risky government debt. The households' optimization problem must also satisfy the following transversality condition:

$$
\lim _{j \rightarrow \infty} E_{t} \beta^{j+1} \frac{\lambda_{t+j+1}}{\lambda_{t}}\left(1-\delta_{t+j+1}\right) b_{t+j}=0
$$

Since the foreign government will never default on its debt, foreign bonds $\left(B_{t}^{*}\right)$ pay the risk-free rate $\left(R_{t}^{f}\right)$. In this case we have the standard intertemporal Euler equation:

$$
\lambda_{t}^{*}=\beta R_{t}^{f} E_{t} \frac{\lambda_{t+1}^{*}}{\pi_{t+1}^{*}}
$$

where $\lambda_{t}^{*}=c_{t}^{*-\sigma}, \pi_{t+1}^{*}=\frac{P_{t+1}^{*}}{P_{t}^{*}}$. Using both Euler equations in the two countries $((6)$ and (8)), we can derive an arbitrage condition linking the real exchange rate, $R E R_{t}=\frac{P_{t}^{*}}{P_{t}}$, to differences in nominal interest rates and consumption levels

$$
R E R_{t}=\Gamma_{0} \frac{\lambda_{t}}{\lambda_{t}^{*}} \frac{R_{t-1}^{f}}{R_{t-1}\left(1-\delta_{t}\right)}
$$

where $\Gamma_{0}=R E R_{0} \frac{\lambda_{0}}{\lambda_{0}^{*}} \frac{R_{0}^{f}}{R_{0}\left(1-\delta_{1}\right)}=1$, is a constant including only initial conditions for asset holdings and interest rates, which we assume equal to 1 to simplify the analysis. 


\section{$2.2 \quad$ Final consumption goods}

Households consume the following basket of final goods produced at home, $c_{H, t}$, and abroad, $c_{F, t}$,

$$
c_{t}=\left(\frac{c_{H, t}}{\eta}\right)^{\eta}\left(\frac{c_{F, t}}{1-\eta}\right)^{1-\eta}
$$

where $\eta$ represents the preference by home consumers for goods produced at home. There exists home bias in consumption when $\eta>\frac{1}{2}$. The demand for final goods produced at home and abroad and the home consumer price index are

$$
\begin{gathered}
c_{H, t}=\eta\left(\frac{P_{F, t}}{P_{H, t}}\right)^{1-\eta} c_{t}=\eta t o t_{t}^{1-\eta} c_{t} \\
c_{F, t}=(1-\eta)\left(\frac{P_{F, t}}{P_{H, t}}\right)^{-\eta} c_{t}=(1-\eta) t o t_{t}^{-\eta} c_{t} \\
P_{t}=P_{H, t}^{\eta} P_{F, t}^{1-\eta}
\end{gathered}
$$

where tot $_{t}=P_{F, t} / P_{H, t}$ represents the relative terms of trade.

\section{$2.3 \quad$ Final intermediate goods}

Differentiated Intermediate goods produced at home $y_{H, t}(h)$ are bundled together into final home intermediate goods $y_{H, t}$, according to the following technology:

$$
y_{H, t}=\left[\left(\frac{1}{s}\right)^{\frac{1}{\theta}} \int_{0}^{s} y_{H, t}(h)^{\frac{\theta-1}{\theta}} d h\right]^{\frac{\theta}{\theta-1}}
$$

where $\theta$ represents the elasticity of substitution between different good-varieties, equal across regions, and $\frac{\theta}{\theta-1}$ is the price mark-up. These final intermediate goods can be used to produce final home or foreign consumption goods $\left(c_{H, t}(h)\right.$ or $\left.c_{H, t}^{*}(h)\right)$ and home public spending $\left(g_{t}\right)$. Cost minimization on the part of final goods producers results in the following demand curve for the intermediate home good, $y_{H, t}(h)$, and the corresponding home producer price index, $P_{H, t}$,

$$
\begin{gathered}
y_{H, t}(h)=\frac{1}{s}\left(\frac{p_{H, t}(h)}{P_{H, t}}\right)^{-\theta} y_{H, t}, \\
P_{H, t}=\left[\frac{1}{s} \int_{0}^{s} p_{H, t}(h)^{1-\theta} d h\right]^{\frac{1}{1-\theta}} .
\end{gathered}
$$




\subsection{Intermediate goods production}

Intermediate goods producers adopt a linear production technology, $y_{t}(h)=a_{t} n_{t}(h)$, with real marginal costs, $m c_{t}(h)=\frac{P_{t}}{P_{H, t}} \frac{w_{t}}{a_{t}}{ }^{1}$ and technology $a_{t}$, assumed constant $\left(a_{t}=a\right)$. These firms enjoy some monopoly power in producing a differentiated product and therefore face a downward sloping demand curve, but are also subject to Rotemberg (1982) quadraticadjustment costs in changing prices. That is, in each period, firms pay a cost proportional in real terms to aggregate real income $\operatorname{pac}_{t}(i)=\frac{\psi}{2}\left(\frac{P_{H, t}(i)}{\pi P_{H, t-1}(i)}-1\right)^{2} y_{t}$ to be able to change their prices and this penalizes large price changes in excess of steady state inflation rates. The dynamic problem of firm $h$ is:

$$
\max _{n_{t}(h), P_{H, t}(h)} E_{t} \sum_{t=\tau}^{\infty} \beta^{t} \frac{\lambda_{t}}{\lambda_{\tau}}\left[\frac{P_{H, t}(h)}{P_{H, t}} y_{t}(h)-m c_{t} y_{t}(h)-\frac{\psi}{2}\left(\frac{P_{H, t}(h)}{\pi P_{H, t-1}(h)}-1\right)^{2} y_{t}\right]
$$

subject to:

$$
y_{t}(h)=a n_{t}(h)=\left(\frac{P_{H, t}(h)}{P_{H, t}}\right)^{-\theta} y_{t}
$$

The first order condition after imposing symmetry across firms is

$$
(1-\theta)+\theta m c_{t}-\psi\left(\frac{\pi_{H, t}}{\pi}-1\right) \frac{\pi_{H, t}}{\pi}+\psi \beta E_{t}\left[\frac{\lambda_{t+1}}{\lambda_{t}}\left(\frac{\pi_{H, t+1}}{\pi}-1\right) \frac{\pi_{H, t+1}}{\pi} \frac{y_{t+1}}{y_{t}}\right]=0
$$

which represents the home non-linear New Keynesian Phillips curve (NKPC) under Rotemberg pricing.

\subsection{Government}

The government (of each country member of the union) finances unproductive purchases $\left(g_{t}\right)$ by collecting tax revenue and issuing one-period bonds $\left(B_{t}\right)$. The tax revenue is raised through a distortionary time varying tax rate $\left(\tau_{t}\right)$ on labor income. The government sets the distortionary tax according to a tax rule and therefore, contrary to the literature on strategic default (Eaton and Gersovitz (1981), Arellano (2008), Mendoza and Yue (2012) and Dovis (2019)), it does not internalize the fact that it may default on its debt. It faces the following budget constraint:

$$
\frac{B_{t}}{R_{t}}+\tau_{t}\left[1-\frac{\psi}{2}\left(\frac{\pi_{H, t}}{\pi}-1\right)^{2}\right] P_{H, t} y_{t}=\left(1-\delta_{t}\right) B_{t-1}+P_{H, t} g_{t}
$$

\footnotetext{
${ }^{1}$ Note that we have defined the real wage in terms of the CPI $\left(w_{t}=\frac{W_{t}}{P_{t}}\right)$, while the real marginal cost is defined in terms of domestic PPI $\left(m c_{t}(h)=\frac{M C_{t}(h)}{P_{H, t}}\right)$
} 
Note that in the case of the home country, where default may happen, the relevant stock of debt is the one net of default $\left(\left(1-\delta_{t}\right) B_{t-1}\right)$. We assume only domestic households may purchase domestic government bonds, that is, there is total home bias on domestic debt. In our model, default is costless in the sense that the defaulting government is neither forced to reform its policies by dramatically reducing deficits, nor is it locked out of credit markets for some period. The government's budget constraint can be rewritten in real terms as

$$
\frac{b_{t}}{R_{t}}+\frac{\tau_{t}\left[1-\frac{\psi}{2}\left(\frac{\pi_{H, t}}{\pi}-1\right)^{2}\right] y_{t}-g_{t}}{t_{o t}^{1-\eta}}=\frac{\left(1-\delta_{t}\right) b_{t-1}}{\pi_{t}}
$$

where $b_{t}=B_{t} / P_{t}$ is real government debt.

The distortionary tax is set according to a simple tax rule ${ }^{2}$

$$
\tau_{t}=\tau+\gamma_{b}\left(b_{t-1}-b\right)
$$

where $\gamma_{b}>0$ is the tax adjustment parameter, so that a larger $\gamma_{b}$ means that the government is more willing to retire debt by raising the tax rate, making debt converge back quicker to its long-run steady state. We assume that government purchases follow an AR(1) process

$$
\ln \frac{g_{t}}{g}=\rho^{g} \ln \frac{g_{t-1}}{g}+\varepsilon_{t}^{g}
$$

where $g$ is the steady state government purchase at home.

\subsection{Monetary policy}

The Central Bank of the Monetary Union sets the gross nominal interest rate to stabilize union-wide inflation and follows a regime-switching process:

$$
R_{t}= \begin{cases}R+\alpha_{\pi}\left(\pi_{M U, t}-\pi_{M U}\right), & \text { if } s_{t}^{R}=1 \\ 1, & \text { if } s_{t}^{R}=2\end{cases}
$$

where $\alpha_{\pi}$ is the policy response to union-wide inflation, and $\pi_{M U, t}=s \pi_{t}+(1-s) \pi_{t}^{*}$. In a Taylor rule regime $\left(s_{t}^{R}=1\right)$, the Central Bank obeys the Taylor principle and in a zero lower

\footnotetext{
${ }^{2}$ The fiscal rule and the fiscal limit represent different constraints to the accumulation of public debt. The former ensures that the fiscal level is bounded and does not enter into an explosive path. The fiscal limit simply reflects the fact that there may be some level of debt that even when stable, it cannot be financed given the tax system and the political constraints in the country, and that gives rise to a non zero probability of default.
} 
bound regime $\left(s_{t}^{R}=2\right)$, the Central Bank exogenously pegs the gross nominal interest rate at 1 . Thus, all ZLB events are due to exogenous changes in $s_{t}^{R}$, and the switches between the two monetary policy regimes are similar to large exogenous shocks. ${ }^{3}$

The monetary policy regime index $s_{t}^{R}$ evolves according to the transition matrix

$$
\left(\begin{array}{cc}
p_{1} & 1-p_{1} \\
1-p_{2} & p_{2}
\end{array}\right)
$$

where $p_{1}\left(p_{2}\right)$ is the probability of continuing to stay in the Taylor rule (ZLB) regime each period, calibrated to be persistent.

\subsection{Union-wide demand and market clearing}

Union-wide demand for home goods, $y_{t}^{D}$, comes from the producers of home and foreign final consumption goods $\left(c_{H, t}, c_{H, t}^{*}\right)$, home government spending (assuming absolute home bias in government spending $\left.g_{H, t}=g_{t}^{4}\right)$ and to pay for price adjustment costs

$$
y_{t}^{D}(h)=s c_{H, t}(h)+s g_{H, t}(h)+(1-s) c_{H, t}^{*}(h)+\frac{\psi}{2}\left(\frac{\pi_{H, t}}{\pi}-1\right)^{2} y_{t} .
$$

Substituting the demands from (15) above we get ${ }^{5}$

$$
y_{t}^{D}(h)=\left(\frac{p_{H, t}(h)}{P_{H, t}}\right)^{-\theta}\left(\frac{t o t_{t}^{1-\eta}}{s} c_{M U, t}^{H}+g_{t}\right)+\frac{\psi}{2}\left(\frac{\pi_{H, t}}{\pi}-1\right)^{2} y_{t}
$$

where we define union-wide private consumption of home produced goods as $c_{M U, t}^{H}=\eta c_{t}+$ $\eta^{*} \frac{1-s}{s} c_{t}^{*}$.

The real exchange rate, the ratio of relative consumption price levels, can be expressed as the ratio of the home and foreign producer prices

$$
R E R_{t}=\frac{P_{t}^{*}}{P_{t}}=\left(\frac{P_{F, t}}{P_{H, t}}\right)^{\eta-\eta^{*}}=t o t_{t}^{\eta-\eta^{*}}
$$

\footnotetext{
${ }^{3}$ We impose the ZLB by exogenous regime switching in monetary policy rules, similar to Richter and Throckmorton (2015), to minimize the number of state variables in solving the nonlinear model. In section 5 , the responses of the real interest rate from fiscal shocks are qualitatively similar to the ones that would be found under endogenous ZLB events.

${ }^{4}$ This is a reasonable assumption since the import content of government spending in the largest Euro Area countries is very small, at around $10 \%$.

${ }^{5}$ We assume the law of one price holds: (i.e.: the price of variety $h(f)$ of the home (foreign) good is equal at home and abroad).
} 
To derive the equilibrium in the goods market in the home country we equate the demand for each intermediate good producer of the home product, equation (26), with its production function $y_{t}^{D}(h)=y_{t}(h)$ and aggregate across all home intermediate firms $\int_{0}^{s} y_{t}(h) d h$ to get

$$
a n_{t}\left[1-\frac{\psi}{2}\left(\frac{\pi_{H, t}}{\pi}-1\right)^{2}\right]=\operatorname{tot}_{t}^{1-\eta} c_{M U, t}^{H}+g_{t}
$$

where we have defined home aggregate labor as $n_{t}=\int_{0}^{s} n_{t}(h) d h$.

Union-wide output is defined as

$$
y_{M U, t}=s y_{t}+(1-s) y_{t}^{*}
$$

Finally, as the representative household at Home is a pool of identical units trying to hedge aggregate risk and we do not allow them to purchase risk-free bods from the foreign government, there is zero net supply of home's risk-free bonds. Hence, provided that the Euler conditions for Home risk-free and risky bonds hold, only the latter are traded to satisfy the government's budget constraint. This final condition closes our economy.

\section{Calibration}

The model is calibrated at a quarterly frequency. In general, the home country is calibrated using data for Spain and the foreign country using data for Germany. However, there are a number of parameters which are common across countries. The household discount rate is 0.99. Preference over consumption are logarithmic, so $\sigma=1$. The inverse of the Frisch elasticity of labor supply is set to $\varphi=1$. The productivity levels at the steady state are normalized to 1 .

The price elasticity of demand, $\theta$, is assumed to be 11, indicating a steady state markup of 10 percent. Alvarez et al. (2006) and Vermeulen et al. (2012) find that prices in the euro area are sticky and price durations are significantly longer than in the US. In addition, survey results show that in the euro area about two-thirds of firms do not change their prices more than once a year (Fabiani et al., 2005). In line with this empirical evidence, we set the Rotemberg adjustment parameter, $\psi$, to 357.5 , which implies that 15 percent of the firms reoptimize prices each quarter. ${ }^{6}$

\footnotetext{
${ }^{6}$ See Ascari and Rossi (2012) for the equivalence of the first-order condition on the NK Phillips curve for the Rotemberg and Calvo specifications on price stickiness.
} 
Table 1: Parameter calibration

\begin{tabular}{|c|c|c|}
\hline parameters & values & \\
\hline$\beta$ & 0.99 & the discount factor \\
\hline$\sigma$ & 1 & inverse of the intertemporal elasticity of substitution \\
\hline$\varphi$ & 1 & inverse of Frisch elasticity of labor supply \\
\hline$\theta$ & 11 & elasticity of substitution \\
\hline$\psi$ & 357.5 & Rotemberg adjustment parameter \\
\hline$\eta$ & 0.63 & home country bias in home goods \\
\hline$\eta^{*}$ & 0.37 & foreign country bias in home goods \\
\hline$s$ & 0.36 & share of home country \\
\hline$b / y$ & 0.6 & steady state debt to output ratio (home) \\
\hline$b^{*} / b^{*}$ & 0.6 & steady state debt to output ratio (foreign) \\
\hline$g / y$ & 0.183 & steady state gov spending to output ratio (home) \\
\hline$g^{*} / y^{*}$ & 0.187 & steady state gov spending to output ratio (foreign) \\
\hline$\tau$ & 0.3005 & steady state income tax rate (home) \\
\hline$\tau^{*}$ & 0.3425 & steady state income tax rate (foreign) \\
\hline$\gamma_{b}$ & 0.04 & tax response parameter to changes in debt \\
\hline$\rho^{g}, \rho^{g *}$ & 0.9 & $\mathrm{AR}(1)$ coefficient in government spending rules \\
\hline$\sigma_{g}, \sigma_{g *}$ & 0.01 & standard deviation of government spending shock \\
\hline$\alpha_{\pi}$ & 1.5 & Taylor rule parameter to inflation \\
\hline$p_{1}$ & 0.9917 & regime-switching parameter for the normal monetary policy regime \\
\hline$p_{2}$ & 0.65 & regime-switching parameter for the ZLB regime \\
\hline$\delta$ & 0.07 & quarterly haircut on debt if default occurs \\
\hline
\end{tabular}

The two countries are assumed to have the same degree of home bias, $\eta=1-\eta^{*}=0.63$, calibrated from Euro Area's import share. We calibrate the size of the home country by comparing the nominal GDP of the Euro Area periphery (Spain \& Italy) vs core (Germany $\&$ France), and $s=0.36 .^{7}$ The fiscal parameters are calibrated to match Spain and German data since the creation of the euro area (1999-2016). In steady state, government purchases are 18.3 and 18.7 percent of GDP, respectively, and the tax rates are 0.3005 and 0.3425 , while the steady state debt-to-GDP ratio is 0.6 for both countries and the model implied lump-sum transfers are 9.5 and 13 percent of GDP. The tax adjustment parameter in the fiscal rule $\gamma_{b}$

\footnotetext{
${ }^{7}$ Thus, the relative size of the domestic economy $(s=0.36)$ is meant to encompass a broader group of countries in the union with comparable debt sustainability problems, so that fiscal responses in this group of countries exert some meaningful effects on the monetary union as a whole.
} 
is calibrated to 0.04 . The magnitude of fiscal adjustments is kept small, just sufficient to satisfy the transversality condition for government debt.

The shock processes for $g_{t}$ and $g_{t}^{*}$ are calibrated on the basis of the empirical evidence available for the euro area and Spain and Germany. For instance, Gadatsch et al. (2015) and Batini et al. (2018) estimate a model of a monetary union with Spain and Germany as members and get the following parameter values for the government spending processes: $\rho^{g}=\rho^{g^{*}}=0.9$ and $\sigma^{g}=\sigma^{g^{*}}=0.01$. These numbers are in line with the theoretical literature (see Schmitt-Grohe and Uribe (2007)).

The steady-state inflation rate is assumed to be $\pi=1$ for simplicity. The Taylor rule parameter is $1.5 .^{8}$ For the transition probability in the regime switching process of monetary policy, we use $p_{1}=0.9917$, which gives an average length of a Taylor rule regime of 30 years, and a less persistent ZLB regime is required to maintain the stationarity of the equilibrium system. We calibrate $p_{2}=0.65$, which implies an average length of a ZLB regime of 2.8 quarters.

Our default scheme assumes a constant haircut rate, $\delta$. We follow Bi (2012) who uses the estimated haircut rates of sovereign debt restructures in emerging market economies between 1998 and 2005 from Sturzenegger and Zettelmeyer (2008), and calculates that 90 percent of the annual haircut rates (as a share of all sovereign debt) fall below 0.3. Thus, we assume a constant annual haircut rate of 0.28 , implying a quarterly rate of $\delta=0.07$. Table 1 summarizes the parameter values.

Appendix A lists equations that characterize the equilibrium system. We use the monotone mapping method of Coleman (1991) and Davig (2004) to obtain a fully-nonlinear solution. Appendix B describes the numerical solution method.

\section{Fiscal limit distribution}

\subsection{Simulating fiscal limit distribution}

Fiscal limits are defined, following Bi (2012), as the present value of maximum future primary surpluses over an infinite horizon. When the tax revenue reaches its peak, the expected present value of future primary surpluses is maximized, given the level of government expenditures. Government expenditures, monetary policy regimes, and institutional quality vary with the stochastic shocks hitting the economy, generating a distribution for the maximum debt level that a government is able to service.

\footnotetext{
${ }^{8} \mathrm{Bi}$ et al. (2018) show that a higher Taylor rule parameter is needed when the rule is targeting the risky rate and the haircut $\delta$ is sizable. On the contrary, this is not the case when the rule is targetting the risk-free rate like in our model.
} 
Since the fiscal limits are the maximum level of debt that can be supported without default, when simulating fiscal limits we set $\delta_{t}=0$ for all $t$. We derive the intertemporal government budget constraint given the real government budget constraint, (21), the Euler equation, (6), and the transversality condition, (7),

$$
b_{t-1}=\pi_{t} E_{t} \sum_{j=0}^{\infty} \beta^{j} \frac{\lambda_{t+j}}{\lambda_{t}} \frac{T_{t+j}-g_{t+j}-z}{t o t_{t+j}^{1-\eta}}
$$

Following Bi et al. (2016), fiscal limits are simulated based on (30), but all the variables are computed under $\tau_{t+i}=\tau^{\max }$, the maximum income tax rate a government is willing and able to impose. We set $\tau^{\max }=0.435$, the marginal statutory rate for highest income earners in Spain (above 60,000€ per year) (European Commission, 2018). ${ }^{9}$

$$
\mathcal{B}^{H}\left(\mathcal{S}_{t}\right)=\beta_{t}^{p} \pi^{\max }\left(\mathcal{S}_{t}\right) E_{t} \sum_{j=0}^{\infty} \beta^{j} \frac{1}{\left(t o t^{\max }\left(\mathcal{S}_{t+j}\right)\right)^{1-\eta}} \frac{\lambda^{\max }\left(\mathcal{S}_{t+j}\right)}{\lambda^{\max }\left(\mathcal{S}_{t}\right)}\left(\mathcal{T}^{\max }\left(\mathcal{S}_{t+j}\right)-g_{t+j}-z\right)
$$

The simulated fiscal limits are state-dependent, uncertain and conditional on an initial state of the economy $\mathcal{S}_{t}=\left\{g_{t}, g_{t}^{*}, \operatorname{tot}_{t-1}, s_{t}^{R}\right\}$. This notion of fiscal limit also captures the private sector's perception of the limit, as it uses the stochastic discount factor evaluated at the maximum tax rate, $\beta^{j} \frac{\lambda^{\max }\left(\mathcal{S}_{t+j}\right)}{\lambda^{\max }\left(\mathcal{S}_{t}\right)}$, and allows for a stochastic political risk $\left(\beta_{t}^{p}\right)$ that follows an $\mathrm{AR}(1)$ process,

$$
\ln \frac{\beta_{t}^{p}}{\beta^{p}}=\rho^{\beta^{p}} \ln \frac{\beta_{t-1}^{p}}{\beta^{p}}+\varepsilon_{t}^{\beta^{p}}, \quad \varepsilon_{t}^{\beta^{p}} \sim N\left(0,\left(\sigma^{\beta^{p}}\right)^{2}\right)
$$

Lower $\beta_{t}^{p}$ indicates higher political risk and hence lower fiscal limits. A possible interpretation for this assumption is that the policy makers have a shorter planning horizon than the private sector (Bi et al., 2018).

In the data, risk premia in several European countries start to increase even at lower levels of debt. Setting $\beta^{p}<1$ and $\varepsilon_{t}^{\beta^{p}} \sim N\left(0,\left(\sigma^{\beta^{p}}\right)^{2}\right)$ serves to shift down the mean and increase the dispersion of the fiscal limit, which generates plausible movements in risk premia as observed in the data. In particular, we calibrate the political risk in the home country by using an indicator about the current political situation derived from a Spanish nation-wide

\footnotetext{
${ }^{9}$ Another way to quantify the fiscal limit is the Laffer curve. Bi (2012) derives the peak of the Laffer curve analytically in a real business cycle model. In a nominal model, Bi et al. (2018) assume that the Central Bank is able to set the inflation rate equal to its objective, which allows for a simple solution for the main variables determining the maximum of the Laffer curve. However, in a monetary union setting the aggregate inflation at its target does not guarantee that each country's inflation is also equal to its target, and thus it does not allow for an analytical solution of the Laffer Curve. Trabandt and Uhlig (2011) use a model-based approach to simulate the theoretical Laffer Curve and find that for plausible calibration, the peak of the Laffer Curve for Spain is 0.415 .
} 
sociological survey (see Gil et al. (2017)) to get $\beta^{p}=0.37, \rho^{\beta^{p}}=0.96$, and $\sigma^{\beta^{p}}=0.13$. This allows us to match Spain's risk premium (below $100 \mathrm{bp}$ ) at its current debt level (97\% of GDP).

Figure 2: Distribution of unconditional fiscal limit computed from expression for $B^{H *}$ in (31)

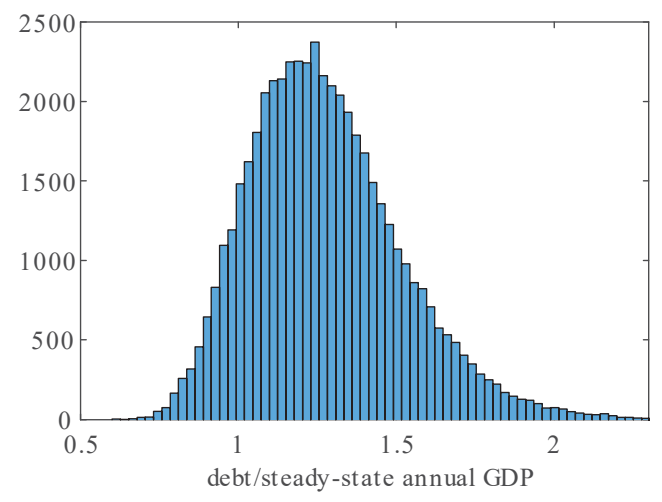

(a) Histogram

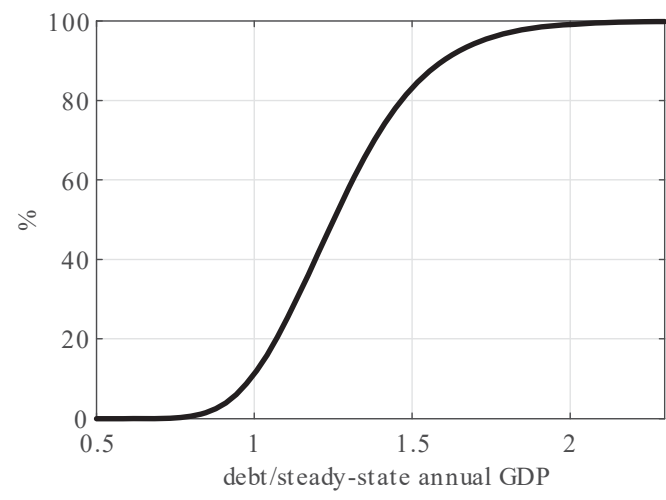

(b) Cumulative density function (cdf)

We simulate the distributions of fiscal limits using Markov Chain Monte Carlo method, which is described in Appendix B.1. As shown in (31), each draw of a fiscal limit from the distribution is conditional on the current state, $\mathcal{S}_{t}$, and particular sequences of realized shocks in the Markov Chain Monte Carlo simulations. When simulating the fiscal limit if the state variables of the system $\left(\mathcal{S}_{t}=\left\{g, g^{*}\right.\right.$, tot, 1$\left.\}\right)$ start from their steady state we define this as the unconditional fiscal limit, while when they start away from their steady state we name it conditional fiscal limit.

\subsection{Unconditional fiscal limit:}

As a baseline, Figure 2 plots the histogram of the simulated unconditional fiscal limits for the home country and the corresponding cumulative density function (cdf), starting from the steady state and a Taylor rule regime $\left(\mathcal{S}_{t}=\left\{g, g^{*}, t o t, 1\right\}\right)$. The x-axis plots fiscal limits in the ratio of government debt to steady-state annual GDP. The histogram in the left panel indicates that the fiscal limit is centered around a debt to GDP ratio of 125 percent $\left(\frac{\overline{\mathcal{B}^{H}}}{y}=1.25\right)$ with a standard deviation $\left(\sigma^{\frac{\mathcal{B}^{H}}{y}}\right)$ of about $0.24 .^{10}$

Although default does not occur when simulating fiscal limits, recall the default mechanism in (3), which makes the role of fiscal limits in default decisions clear,

$$
\delta_{t}=\left\{\begin{array}{lll}
0 & \text { if } \quad b_{t-1}<\mathcal{B}^{H}\left(\mathcal{S}_{t}\right) \\
\delta & \text { if } \quad b_{t-1} \geq \mathcal{B}^{H}\left(\mathcal{S}_{t}\right)
\end{array}\right.
$$

\footnotetext{
${ }^{10}$ The histogram has a slightly longer right tail. This asymmetry is due to the effect of the stochastic process estimated for the political factor, which is bounded above zero and has a fairly large standard deviation. The simulated distribution of the fiscal limit without the political factor is symmetric.
} 
The choice $\mathcal{B}^{H}\left(\mathcal{S}_{t}\right)$, is uncertain and depends on fiscal policy, monetary policy, and political considerations. The fiscal limit defined here describes the stochastic upper bound on how much debt a government is willing and able to service given the economic and political constraints. Therefore, there is a one to one mapping between the cumulative distribution of the home fiscal limit and the probability of the home government defaulting on its debt. Thus, the cumulative distribution function (cdf) of the home fiscal limit in the right panel can be interpreted as the probability of the home government defaulting on its debt, which is nil for debt levels close to 80 percent of GDP, while it converges to 1 for debt levels above 200 percent of GDP. In between those values, the probability of default gradually increases as debt accumulates.

A large literature adopts strategic sovereign default approach in which an optimizing government accounts for some economic costs in making default decisions (Eaton and Gersovitz, 1981; Aguiar and Gropinath, 2006; Arellano, 2008; Yue, 2010; Dovis, 2019). Another literature incorporates default risk by exogenously specifying fiscal limits (Daniel and Shiamptanis, 2012; Corsetti et al., 2013; Batini et al., 2018). Instead, we follow a different approach. Although the government in the model does not optimize over its default decisions, our definition of the fiscal limit captures uncertainty in default risk. Moreover, the fiscal limit, when included in the full model, responds endogenously to economic disturbances, which we will discuss in the next section.

\subsection{Conditional fiscal limit: The effect of fiscal and monetary policy}

In line with the definition of fiscal limit in (31), the state of the economy can have a significant impact upon the default probability in the home country. A change in fiscal or monetary variables changes the household's perception of debt sustainability and thus can shift the fiscal limit. We define the state-dependent fiscal limit as "conditional fiscal limit", and Figure 3a compares the fiscal limit distributions conditional on different initial government spending levels in the home country, while keeping the other state variables at the steady state. In particular, the red-continuous (blue-dashed) line represents the change in the default probability with respect to the Home's unconditional fiscal limit when government spending in the home country starts 10 percent below (above) the steady state value. In the conditional case, with $g_{t}<g\left(g_{t}>g\right)$ spending it is likely to remain below (above) the unconditional case for most simulations since it follows a very persistent process.

A 10 percent increase in home's government spending increases aggregate demand and generates more tax revenues. On the other hand, the fiscal expansion also raises public deficit today and worsens the sustainability perspectives of home government's finances, shifting its fiscal limit to the left and increasing its default probability for debt levels between 
Figure 3: State-dependent distributions of fiscal limits: change in government spending

a) Home gov spending (g)

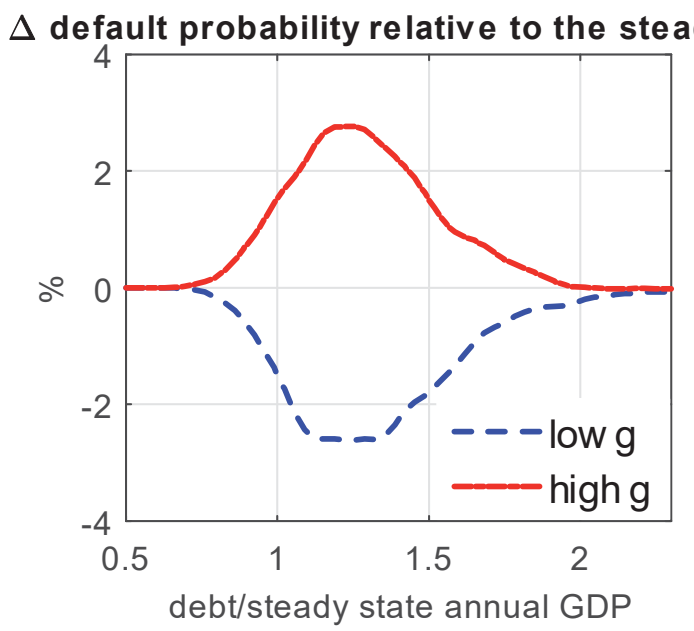

b) Foreign gov spending $\left(\mathrm{g}^{*}\right)$

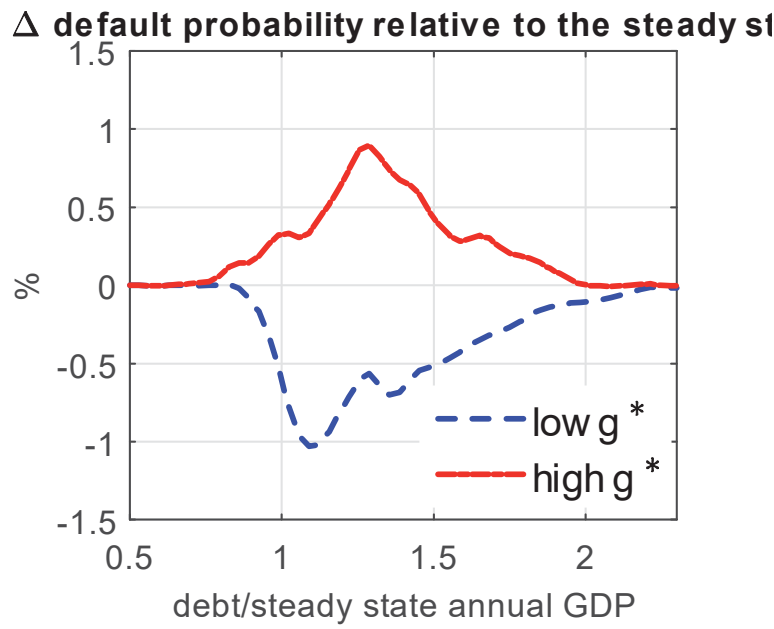

80 and 200 percent of GDP (red-continuous line in figure 3a). The marginal change in the default probability from changes in government spending in the home country is the largest when debt to steady-state annual GDP reaches 120 percent, where the slope of the estimated cdf is the steepest. On the contrary, a 10 percent fiscal consolidation improves debt sustainability and decreases the default probability. The maximum impact of a 10 percent increase (reduction) in government spending raises (lowers) the default probability by 3 percentage points, that is from 38 percent to 41 percent (to 35 percent), when debt to steady-state annual GDP is 120 percent (blue-dashed line in figure 3a).

When the increase in government spending occurs in the foreign (low debt) country instead, the model generates significant spillover effects on the home country's fiscal limit. Figure 3b shows the change in the default probability of home country's fiscal limit in response to changes in government spending in the foreign country, while keeping the other state variables at the steady state. A $10 \%$ increase in foreign government spending increases its output and inflation. As monetary policy follows the Taylor rule $\left(s_{t}^{R}=1\right)$, given the greater size of the foreign country, fiscal expansions lead to higher nominal interest rate, which also raises the real interest rate in the home country, thus depressing the home country's demand and increasing its financing cost of debt. This monetary channel worsens the perspectives of home country's public finances, reducing its fiscal limit (shifts the cdf to the left). In addition, as we assume absolute home bias in government spending and there is no complementarity between public and private consumption (since public spending does not enter the consumers' preferences), increasing foreign government spending crowds out foreign private consumption and therefore lowers foreign demand for home goods, which reduces exports in the home country. The negative trade channel reinforces the negative 
monetary channel that increases the home country's default probability (red-continuous line in figure 3b). In quantitative terms, the negative spillover effect of a fiscal expansion abroad on home's probability of default on its public debt is about a third of the size of the direct effect of its own fiscal expansion. ${ }^{11}$

Figure 4: State-dependent distributions of fiscal limits under the ZLB: government spending
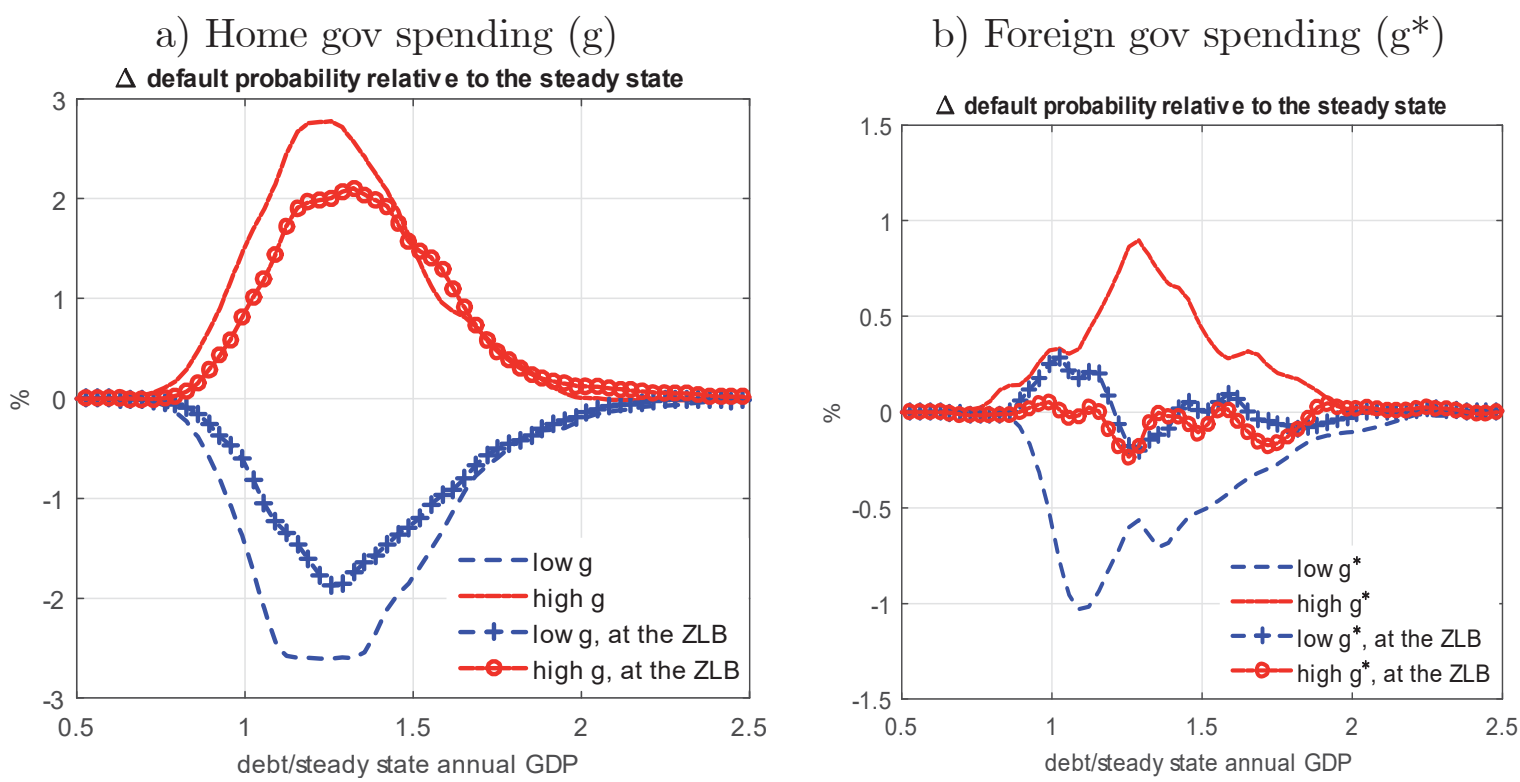

When the ZLB is binding, changes in the default probability in response to changes in home government spending are smaller relative to the Taylor rule regime. In this sense, Figure 4a shows the fiscal limit conditional on starting the simulations under a binding ZLB monetary regime and then letting monetary policy evolve according to expression (24). In a Taylor rule regime, a high government spending in the home country increases the real interest rate, lowering demand and worsening fiscal sustainability. The binding ZLB, on the other hand, counteracts the effects on real interest rates. As the nominal interest rate is constrained, the expectation of higher inflation caused by the rise in government spending lowers the real interest rate, increasing domestic demand and generating more tax revenue. So the worsening in the fiscal limit due to the increase in the fiscal deficit is somewhat compensated by the improvement due to the fall in the real interest rate. Therefore, the net effect is a smaller worsening in the present value of future primary surpluses and in the default probability in the ZLB regime compared to the Taylor rule regime.

Figure $4 \mathrm{~b}$ shows that being in the ZLB regime mitigates almost completely the impact of changes in foreign government spending on the default probability. As mentioned earlier, in

\footnotetext{
${ }^{11}$ This negative trade channel could be mitigated by allowing public spending to be a basket of home and foreign goods and/or assuming that consumers derive utility from the provision of public goods, which then become complements of private consumption and thus reduce the crowding-in effects. However, the quantitative relevance of the former element is very small in reality, since the weight of foreign goods in government spending is close to 10 per cent for most euro area countries.
} 
a Taylor rule regime, an increase in foreign's government spending raises demand for foreign goods and lowers demand for home goods, which decreases home country's export. The negative trade channel is still present and brings up the default probability. However, when the ZLB is binding, nominal rates do not rise and the negative trade channel is counteracted by a fall in the real interest rate, making the increase in the default probability smaller.

The impact of the binding ZLB on default probabilities, depends critically on the persistency of the ZLB regime. If the ZLB regime is expected to last for longer, the response of real interest rates to inflation expectations is augmented and the monetary channel gets stronger. As we calibrate the average duration of the ZLB regime to be relatively short, the quantitative impact of the ZLB regime as shown in Figure 4 can be understood as a lower bound. If the persistency in the ZLB regime were higher, the positive monetary channel could dominate the negative trade channel after an increase in foreign government spending, which could even reduce the default probability.

Finally, the exercises of this section confirm our modelling choice to have the home country, representing a high debt country with the possibility of default, while the foreign country does not. In particular, we find that the endogenous fiscal limit in our model is relevant when the home country has a debt level above 80 percent of GDP; beyond that threshold, fiscal and monetary shocks induce significant changes in the sustainability of home's public finances. This is also consistent with the current levels of debt observed in EMU as shown in Figure 1, which are around 100 percent in Spain, France and Belgium, above 130 percent in Italy, while close to 60 percent in Germany.

\subsection{Exogenous Fiscal Limit}

As mentioned in the introduction, previous papers in the literature study the effects of exogenous fiscal limits in a monetary union. In fact, Corsetti et al. (2013), Corsetti et al. (2014) and Batini et al. (2018) allow for the possibility of home government default on public debt that hence pays a risk premium, but such premium only depends on the level of debt and it does not respond to other dimensions of the economic environment. In these papers the fiscal limit follows a distribution (normally a logistic or beta) which is a function only of the country's debt to GDP ratio. Therefore, a fiscal consolidation in these models only affects the risk premium through its effects on debt. As this is a slow moving predetermined variable, the risk premium cannot jump at the time of the announcement of a policy based on the expected future fiscal developments. To compare our setting to the previous literature, although the fiscal limit is model-based, we map the simulated unconditional fiscal limit (as shown in Figure 2b) to a logistic function, which we use as an exogenous fiscal limit. In terms of our default equation, 3 , this is equivalent to making $\mathcal{B}^{H}()$ a logistic function of $b_{t-1}$. 
We name this version of the model the "exogenous fiscal limit" case. Finally, to compare our results to those obtained from a model without risk premium, we set $\delta=0$ in equation 3 , which we name "no default case".

\section{$5 \quad$ Fiscal policy in a monetary union}

We now present several fiscal policy exercises with the full non-linear model incorporating the state-dependent fiscal limit discussed in the previous section arising from the possibility of the home country government to default on its debt. We concentrate on fiscal issues since these are very much in the current policy debate in the monetary union and it is precisely the economic policy where a state-dependent fiscal limit ought to be more relevant. First, we analyze the long-term process of public deleveraging that is required for high-debt countries to converge back to the target levels set by European authorities and that we consider the steady state in our calibration. We also study how the speed of fiscal adjustments determines its cost. Second, we look at the effect of discretionary policy measures along this process of convergence. In particular, we will show the effect on the economy of a transitory fiscal consolidation in a member of the euro area with high debt and a fiscal policy coordination between both countries. These cases are analyzed under two alternative assumptions about the monetary policy space in the union depending on whether the Taylor rule is operative or the economy is temporarily stuck at the zero lower bound so that the nominal interest rate cannot be reduced any further.

\subsection{Long-run fiscal consolidation at home}

One of the current main challenges in the euro area is for high debt countries to converge back towards more sustainable debt levels. In fact, the Stability and Growth Pact (SGP) sets a limit of 60 percent of GDP for public debt, beyond which the debt rule is active. ${ }^{12}$ Given the high level of government debt in many countries, this implies a long-term process of consolidation, which could take several decades, and which will affect the area as a whole. This process is the focus of this section.

As shown in the previous section, the state-dependent fiscal limit becomes relevant when debt-to-GDP ratio is around 100 percent, but the steady state debt in both members of the euro area is 60 percent of GDP. Therefore, the policy relevant exercises have to be based on an scenario with high debt in the home country, while the foreign country is at its steady state. In particular, to achieve this we set the initial stock of home debt $\left(b_{t-1}\right)$ to 100 percent of GDP at the beginning of the scenario $(t=0)$, which generates a risk premium of almost

\footnotetext{
${ }^{12}$ The debt rule of the SGP requires a reduction of $1 / 20 t h$ of the distance with 60 per cent each period.
} 
80 basis points, and then, we let the fiscal and monetary rules bring the economy back to its steady state. ${ }^{13}$ This initial state is in line with the situation in Spain and Germany at the end of 2018, with debt to GDP ratios of 97.1 percent and 60.9 percent, respectively, and a spread between the Spanish and German 10-year bonds around $100 \mathrm{bp}$.

Figure 5: Convergence back to the steady state from a high debt scenario at home
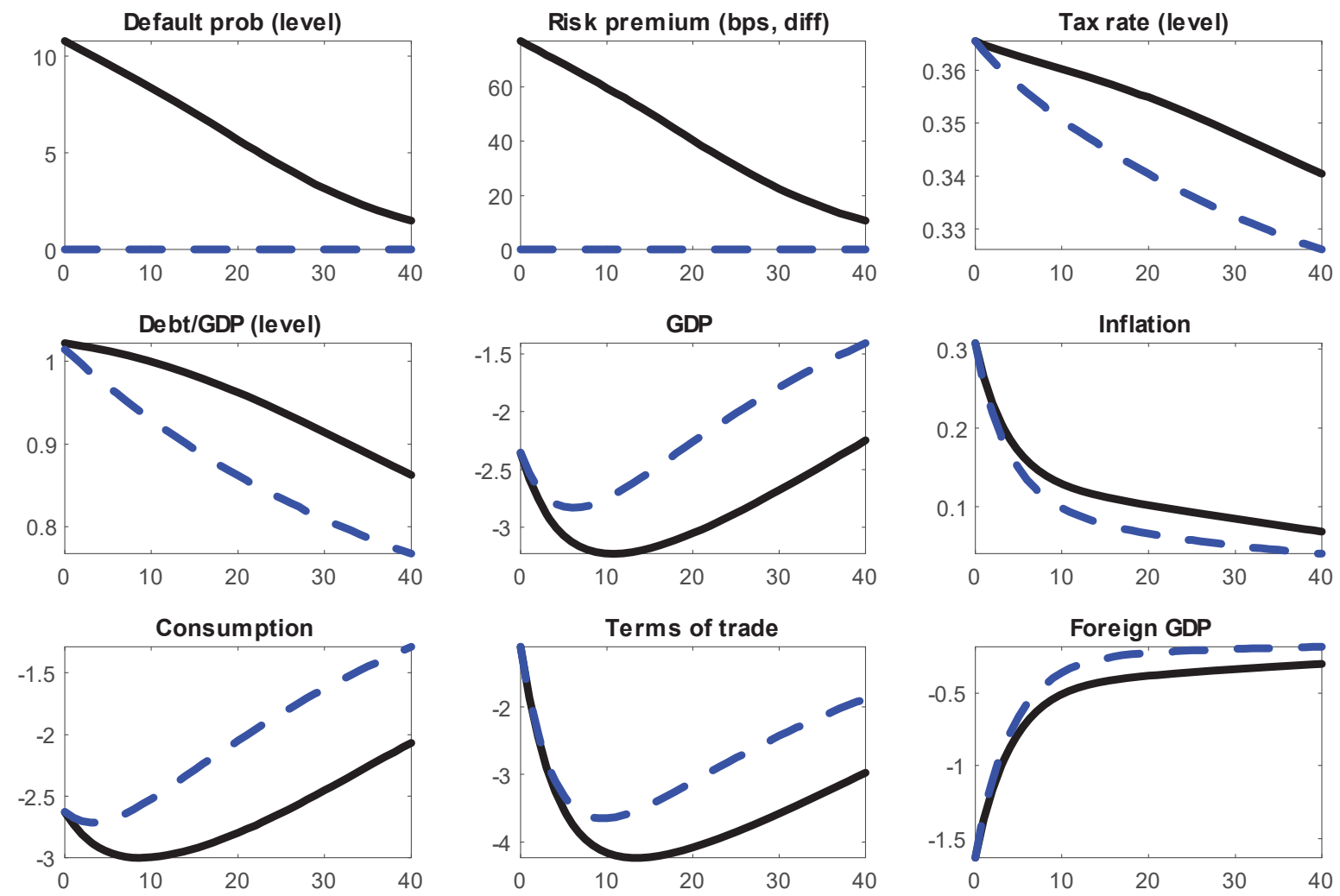

State-dependent FL $\quad-\quad$ No Default

Note: The responses (for those without a parenthesis) are plotted as the differences in percent of stochastic steady-state.

Default probability, risk premium, tax rate, debt-to-annual GDP ratio: level differences in percent of stochastic steady-state.

To highlight the risk premium channel, Figure 5 compares the long-run fiscal consolidation in an economy with risk premium generated by endogenous fiscal limits (solid lines) and an economy without default risk (dashed lines). In both cases, the consolidation process is characterized by an increase in income tax rates, as implied by the fiscal rule, to slowly reduce debt, which may take more than a decade to reach its steady state level. When the debt-to-GDP ratio is 100 percent, the income tax rate increases to 0.37 , compared to the steady state value of 0.30 . Home GDP and consumption are 2.4 percent and 2.7 percent below their state state values, respectively. In our baseline model with endogenous fiscal limits, the default probability is 11 percent at $t=0$, which produces a risk premium of 77

\footnotetext{
${ }^{13}$ This approach provides a good approximation to the true high debt scenario, since although in our model terms of trade in the previous period $\left(\right.$ tot $\left._{t-1}\right)$ is also a state variable, endogenizing it would have only a negligible effect.
} 
basis points. Although the initial states for the real macroeconomic variables are the same between the two economies, higher risk premium increases the interest burden on debt and produces significant differences in the long run. After ten years, the negative output gap in the economy with risk premium is almost twice as large as the economy without default risk. In the case with risk premium, debt-to-GDP ratio and tax rates are higher for all periods while consumption is lower. This worsens the terms of trade and further deprives activity. The fiscal adjustment in the high-debt economy also spills over to the rest of the euro area, where foreign output falls persistently.

Figure 6: Increasing the speed of convergence back to the steady state from a high debt scenario at home.

a) Frontloading vs gradualism
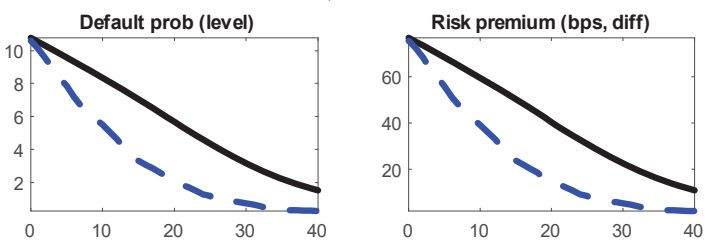

GDP
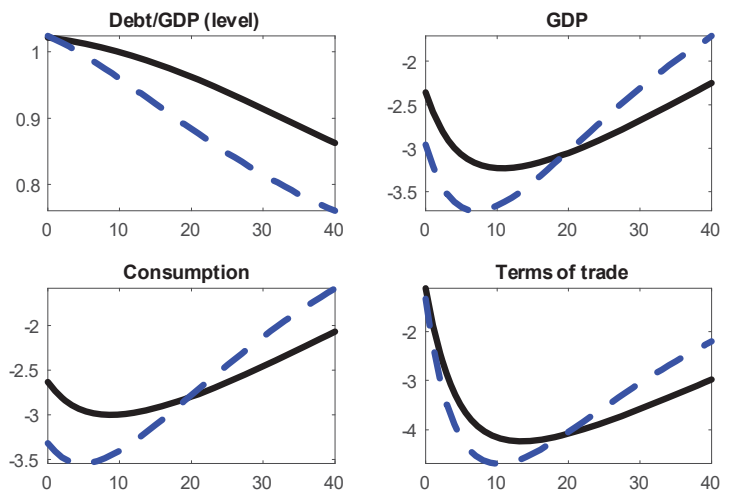

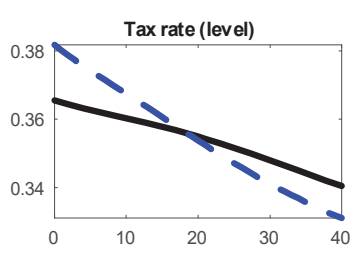

Inflation
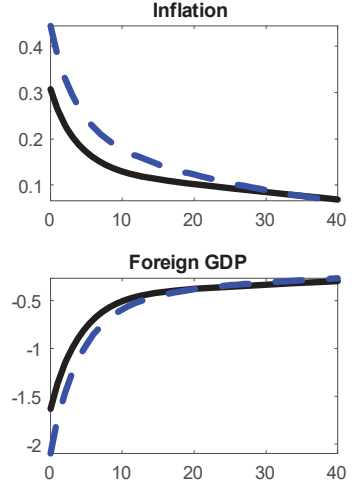

b) State-dependent FL vs no default
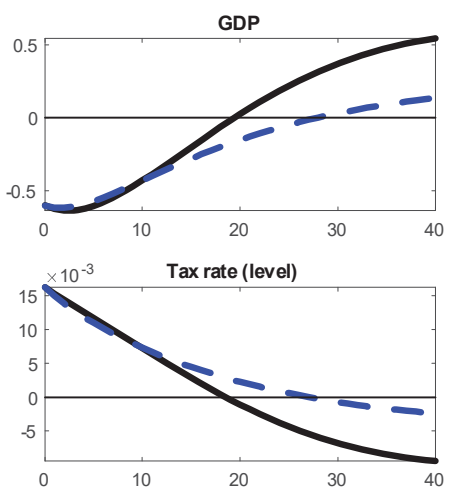

Debt/GDP (level)

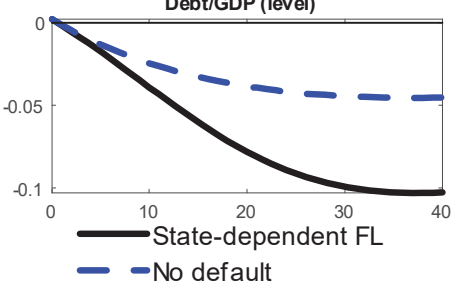

Note: See Figure 6 for units of y-axes. RHS panel: difference between the frontloaded consolidation $(\gamma=0.05)$ and the gradual consolidation $(\gamma=0.04)$.

The long term convergence back towards the 60 percent level of debt will be different depending on the intensity of the consolidation process, which in our model is driven by the parameter of debt on the fiscal rule $(\gamma)$. The presence of a risk premium at high levels of public debt, speaks in favor of a quicker consolidation to reduce the effective borrowing rate, nevertheless, that does not imply that fast consolidations are going to be less painful. As Figure 6a shows, if the country undertakes a faster tax-based consolidation program, which we model as a fiscal rule with $\gamma=0.05$, the GDP loss is not necessarily lower, despite the fact that the government manages to reduce the risk premium much faster. The debt-tooutput ratio falls quicker when the consolidation is more frontloaded ( $\gamma$ is higher) and the 
risk premium returns to zero after roughly seven years, two-thirds of the time it needs to do so with a more backloaded consolidation $(\gamma=0.04)$. As the income tax rate is higher to retire debt sooner, in the frontloaded scenario it has a more negative effect on consumption and GDP, at least in the short to medium run. This is reversed after five years, but the burden of the short run cost carries a high weight.

Nevertheless, the presence of the fiscal limit implies that increasing the speed of consolidation is less painful in an economy with a binding fiscal limit, than in a similar economy operating further away from the fiscal limit. ${ }^{14}$ Figure $6 \mathrm{~b}$ shows that in the latter case (dashed blue line) speeding up the consolidation process induces a larger and more persistent GDP fall relative to the more gradual consolidation, than it does in the economy operating close to the endogenous fiscal limit. In particular, the frontloaded consolidation induces and additional cost in terms of GDP losses that lasts 2 years longer (6.5 vs 4.5 years) in the case of a high debt economy operating away from its fiscal limit than in the one where the limit is binding. This is due to the fact that the more frontloaded consolidation in the economy with the binding fiscal limit reduces significantly more the risk premium, which allows for a quicker reduction in the debt to GDP ratio and in the tax rate.

\subsection{Discretionary fiscal consolidation at home}

To see how government indebtedness matters for discretionary fiscal consolidation effects in the home country, we examine an exogenous government spending cut for different levels of debt, first in the normal (Taylor rule) monetary regime and then when the economy hits the ZLB. The impulse responses shown in this section represent marginal effects. That is, the differential impact when we add a transitory spending cut to the baseline long-term consolidation process described in the previous section. In practice, this means that before the spending cut, the high-debt state at $t=0$ is simulated like in the previous section (the low-debt state is the stochastic steady state of 60 percent) and an additional 1 percent negative government spending shock is injected at $t=0$.

Solid lines in Figure 7 show the macroeconomic responses to a 1 percent transitory government spending cut in a high-debt member of a monetary union. Discretionary fiscal consolidation reduces output and inflation on impact due to lower demand for domestic goods. The real interest rate falls immediately by $10 \mathrm{bp}$ and then slowly gets more negative. Since the home country has a small weight in the Taylor rule, the initial impact on the EA wide nominal interest rate is contained and so is the impact on the real interest rate, but as the output gap is closed, inflation recovers and the real rate falls more significantly.

\footnotetext{
${ }^{14}$ For the sake of simplicity we model the latter case as an economy where there is no default, so that its risk-premium is not affected by the level or the speed of debt reduction. This would be equivalent to a high-debt economy for which the fiscal limit is high enough so that reaching a debt level of $100 \%$ of GDP does not to increase significantly the risk-premium.
} 
Figure 7: Transitory government spending cut at Home.

The effect of initial debt level
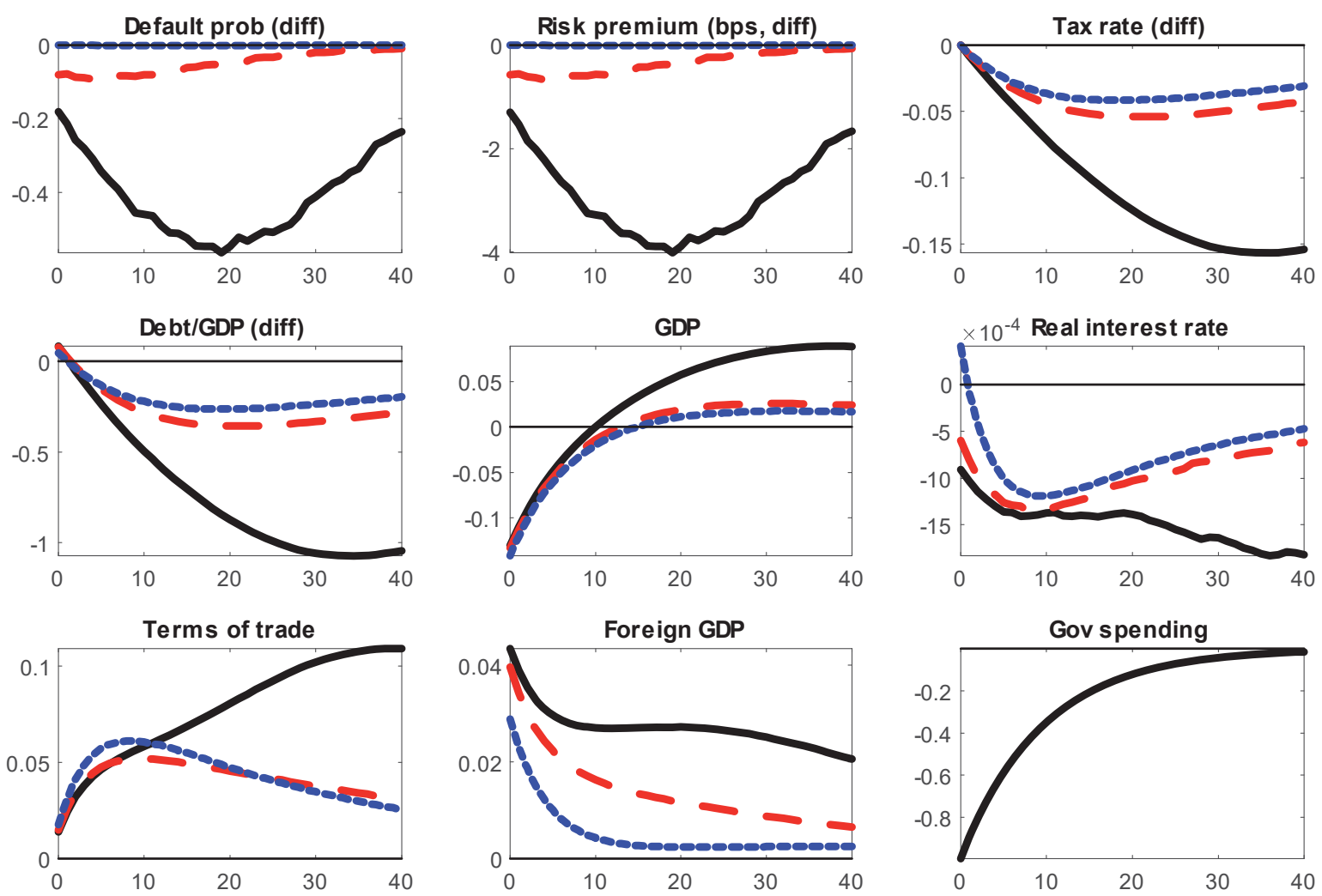

$-b / y=1-b / y=0.9 \cdots \infty-\infty, y=0.6$

Notes: The responses (for those without a parenthesis) are plotted as the differences in percent of stochastic steady-state levels between the paths with and without a $1 \%$ government spending cut.

The default probability, tax rate, and debt/GDP ratio are the level difference in percent and risk premium is the level difference in basis point between the paths with and without the shock.

On the fiscal side, the lower spending reduces the deficit and starts a slow process of debt reduction, while at the same time, the fiscal rule sets a slightly lower tax rate. The public deficit reduction in the short term leads to a slight improvement of the expected medium and long-term sustainability of public finances and to an increase in the home's fiscal limit (see Figure 3a). This has an immediate effect on home government's default probability, which falls on impact and during the first four years by half a percentage point, making the risk premium on home government bonds fall by almost 4 basis points. Both of these effects generate a persistent reduction in home government's cost of financing, which further contributes to the improvement of public finances and to debt reduction. After ten quarters, GDP starts to recover, thanks to the reduction in the home's cost of financing, the improvement in the terms of trade, together with gradual reduction in the tax rate. In addition, the shock produces a positive spillover to the rest of the union, mainly through two channels. 
On the one hand, the fall in activity and inflation at home slightly pushes down the ECB's nominal interest rate and fosters economic activity in the rest of the union. On the other hand, the increase in home's consumption fosters exports from the rest of the union. This leads to a small reduction in foreign debt.

As one would expect, our non-linear model is capable of showing that the benefits from fiscal consolidation are greater when an economy is in a high debt situation than when its public finances are in better shape. The blue dashed lines of Figure 7 depict the effect of the same discretionary spending cut starting from a low level of debt (60 percent of GDP, the stochastic steady state). In this case, home's government finances are in much better shape and therefore very far from the fiscal limit, so the risk premium is close to zero and insensitive to small changes in debt sustainability. Therefore, the discretionary fiscal consolidation cannot improve the probability of default, which is almost nil, and thus does not reduce the risk premium. The output recovery does not benefit from lower interest payments on debt and is therefore much weaker, resulting in a smaller reduction in public debt. The positive spillover effect to the rest of the union, is also smaller. On the contrary, as the initial level of debt gets higher, red dashed-dotted lines represent a 90 percent debt-GDP ratio, the impact of a spending cut on the risk premium starts to have a more significant effect. Moreover, comparing the three cases shows clearly that the effect of the fiscal limit on real activity is very non-linear, increasing very quickly as the high-debt country approaches the fiscal limit. In this sense, it is worth reminding that it does no take a very high probability of reaching the fiscal limit for it to become relevant. According to Figure 2, with a debt to GDP ratio of 100 percent, the economy has barely a 10 percent probability of default on the service of the debt.

In order to study more closely the role of the risk premium in the transmission channel of fiscal shocks. In Figure 8, we compare our model with the two alternative ones previously used in the literature and explained in the previous section: dashed-dotted red lines depict the effect of a fiscal consolidation at home in a standard model without default risk, while the dashed blue lines show the effect in a model with an exogenous fiscal limit (see Davig et al. (2010), Corsetti et al. (2013), Corsetti et al. (2014) and Batini et al. (2018)), in which there is the possibility of home government default and thus it pays a risk premium, but such premium only depends on the level of debt and it does not respond to other dimensions of the economic environment. Therefore, a fiscal consolidation does not trigger an immediate fall in the risk premium upon the policy implementation, but instead the risk premium is reduced slowly as debt falls.

In the model without default risk, reducing public debt does not affect the cost of financing and therefore, the impulse responses look very similar to the ones under a scenario of low 
Figure 8: Transitory government spending cut at Home.

The effect of a state-dependent risk premium
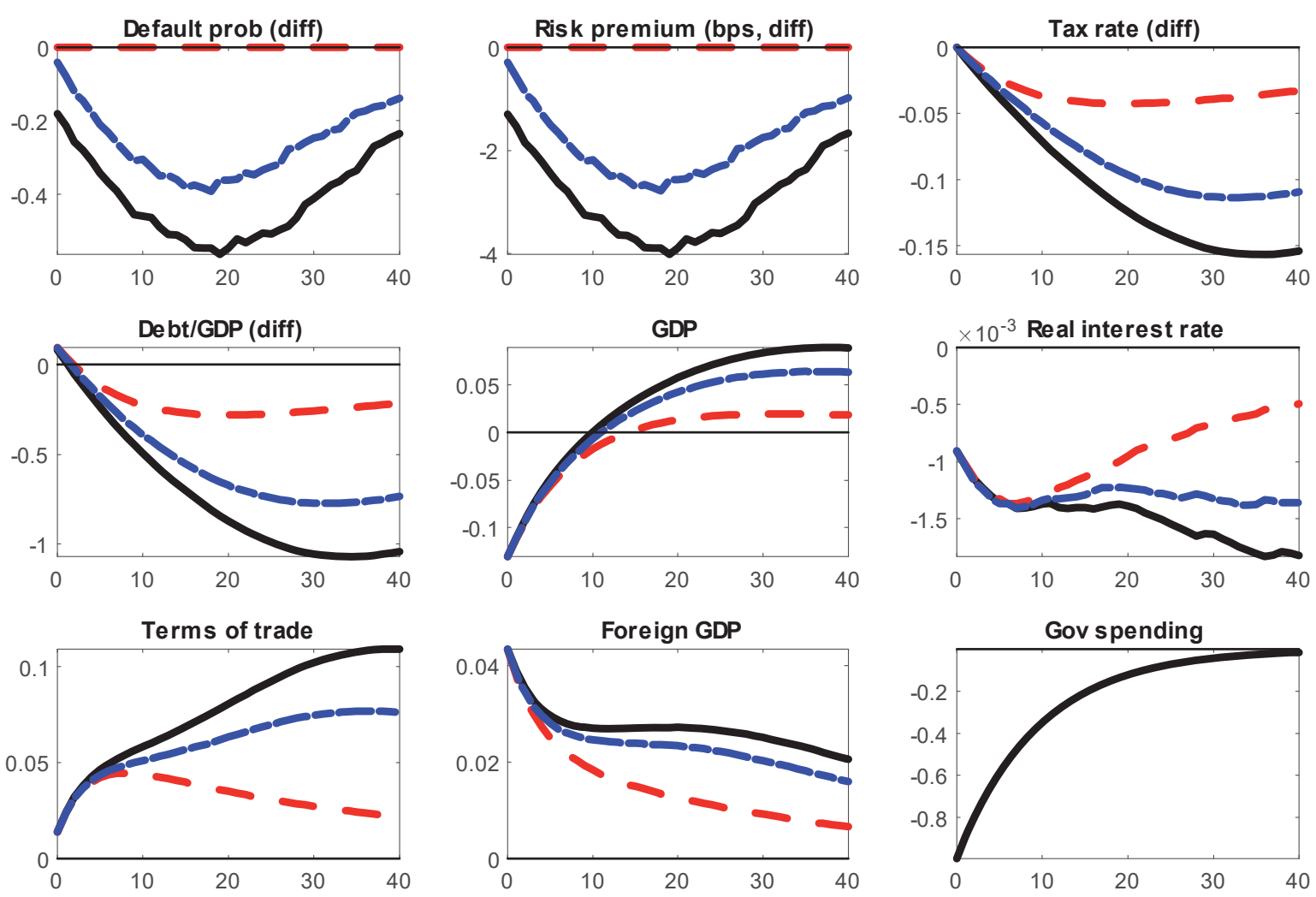

baseline - no default $\longrightarrow$ exogenous FL

Notes: See Figure 8 for units of y-axes.

debt. In the model with exogenous fiscal limits, the fiscal consolidation increases government primary surplus and lowers debt gradually. As public debt adjusts back to its steady state level, the default probability and risk premium decrease slowly, as shown by the dashed blue line. In our model with state-dependent fiscal limits, the discretionary spending cut improves the home government's fiscal outlook and immediately pushes the fiscal limit distribution to the right, improving the home government's debt sustainability. This in turn makes the risk premium jump down on impact, shortening the initial recession and increasing the strength of the recovery. With state-dependent fiscal limits, the decrease in risk premium is almost 2 basis points more than that with exogenous fiscal limits throughout the horizon. These small variations in risk premium can produce significant differences in debt dynamics. After ten years, annual debt-to-GDP ratio decreases by 1.08 percentage points with state-dependent fiscal limits, compared to 0.76 with exogenous fiscal limits. In addition, the more powerful risk premium channel in our model increases the positive spillover effect to the rest of the union.

Key in the outcome of these consolidation scenarios is the monetary regime the union finds itself in. Figure 9 compares our baseline simulation, with an alternative monetary 
Figure 9: Transitory government spending cut at Home.

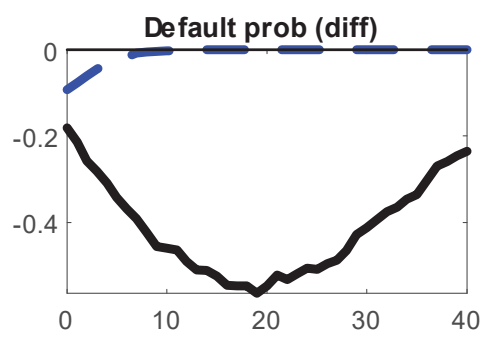

The effect of binding ZLB
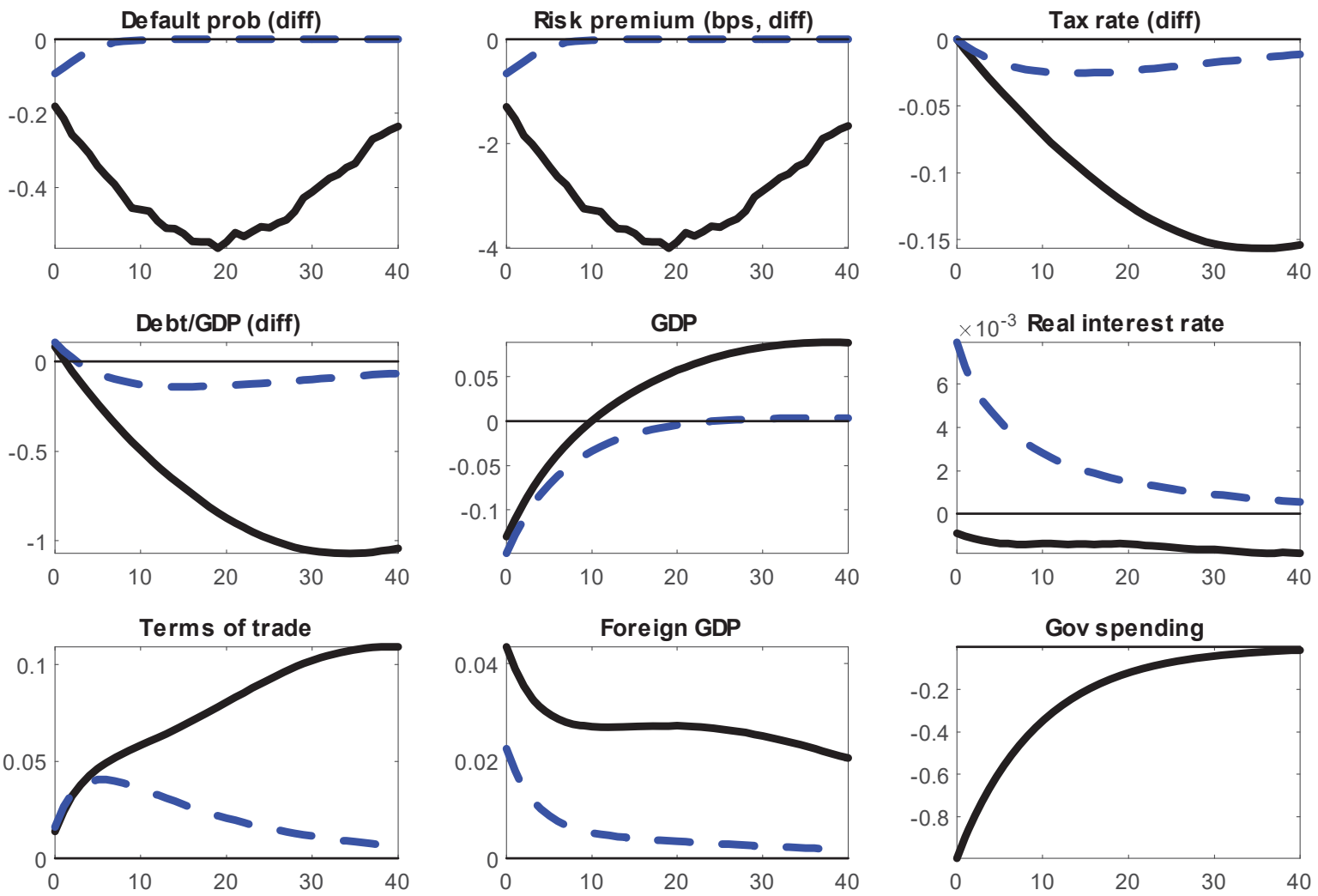

$\longrightarrow$ Normal times - ZLB

Notes: See Figure 8 for units of y-axes.

policy regime at the ZLB. On impact, the reduction in default probability and risk premium under the ZLB regime are smaller than that under the Taylor rule regime, consistent with the fiscal limit distribution in Figure 2b. For the longer horizon, a persistent fiscal consolidation generates deflation expectations. When the nominal interest rate is constrained at zero, the real interest rate is consistently higher than that under the Taylor rule regime. Higher real interest rates lower demand, increase the cost of servicing the debt, mitigating the strength of the risk premium channel explained before. Therefore, under the ZLB the presence of an state-dependent fiscal limit does not make fiscal consolidations as beneficial as they are when monetary policy operates under a Taylor rule.

Table 2 reports the cumulative government spending multipliers for output in the home country, foreign country, and the Euro area for various models, computed as

$$
\frac{\sum_{i=0}^{k}\left(\prod_{j=0}^{i} r_{t+j}{ }^{-1}\right) \triangle x_{t+i}}{\sum_{i=0}^{k}\left(\prod_{j=0}^{i} r_{t+j}{ }^{-1}\right) \triangle g_{t+i}}, \quad x \in\left\{y, y^{*}, y_{M U}\right\}
$$


where $\triangle$ denotes level changes relative to a path without government spending changes. To keep the comparison consistent among different models, we use $r_{t}=\beta^{-1}$ as the real interest rate.

Table 2: Output multipliers from a discretionary government spending cut at home

\begin{tabular}{|c|c|c|c|c|c|c|c|c|c|c|c|c|}
\hline \multirow{2}{*}{$\begin{array}{c}\text { Multiplier } \\
\text { Models }\end{array}$} & \multicolumn{4}{|c|}{$\begin{array}{c}\text { Periphery (home) } \\
\frac{P V(\Delta y)}{P V(\Delta g)}\end{array}$} & \multicolumn{4}{|c|}{$\begin{array}{l}\text { Spillover to core (foreign) } \\
\qquad \frac{P V\left(\Delta y^{*}\right)}{P V(\Delta g)}\end{array}$} & \multicolumn{4}{|c|}{$\begin{array}{l}\text { Euro area } \\
\frac{P V\left(\Delta y_{M U}\right)}{P V(\Delta g)}\end{array}$} \\
\hline & $0 \mathrm{yr}$ & $1 \mathrm{yr}$ & $5 \mathrm{yr}$ & $10 \mathrm{yr}$ & $0 \mathrm{yr}$ & $1 \mathrm{yr}$ & $5 \mathrm{yr}$ & $10 \mathrm{yr}$ & $0 \mathrm{yr}$ & $1 \mathrm{yr}$ & $5 \mathrm{yr}$ & $10 \mathrm{yr}$ \\
\hline No default & 0.71 & 0.66 & 0.44 & 0.24 & -0.18 & -0.17 & -0.21 & -0.25 & 0.14 & 0.13 & 0.03 & -0.08 \\
\hline Exogenous FL & 0.71 & 0.66 & 0.31 & -0.24 & -0.18 & -0.18 & -0.26 & -0.37 & 0.14 & 0.12 & -0.05 & -0.32 \\
\hline State-dependent FL & 0.71 & 0.65 & 0.23 & -0.50 & -0.18 & -0.18 & -0.28 & -0.42 & 0.14 & 0.12 & -0.10 & -0.45 \\
\hline ate-dependent FL, ZLB & 0.82 & 0.77 & 0.63 & 0.56 & -0.09 & -0.08 & -0.07 & -0.09 & 0.23 & 0.22 & 0.18 & 0.15 \\
\hline
\end{tabular}

The fiscal multiplier, measuring the reduction in output due to a 1 euro fall in government spending, is similar the first year after the shock (see rows 1 and 4 of the top panel in Table 2) without or with default risk, but the difference can be sizable in the medium to long run. The ten year cumulative fiscal multiplier after a discretionary government spending cut in a model without sovereign default is 0.24 , it changes its sign, becoming expansionary (-0.24) when default is introduced through exogenous fiscal limits, while the fiscal consolidation becomes more expansionary $(-0.5)$, when a state-dependent fiscal limit is considered. Having fiscal limits respond directly to the economic states amplifies the risk premium channel and makes fiscal consolidation more expansionary for the home country in the long run. For the Euro area, consolidation in the highly-indebted country also results in long run gains. The tenyear multiplier for the Euro area is -0.45 with state-dependent fiscal limits, compared to -0.08 in the model without default. A binding ZLB, on the other hand, mitigates the risk premium channel by weakening demand through a higher real interest rate. The monetary channel can be sizeable, in which the ten-year multiplier for the home country reverses its sign, from -0.5 to 0.56 .

\subsection{Discretionary fiscal coordination}

Following the sovereign debt crises in the euro area, a consensus has emerged about the need of a coherent and integrated fiscal policy strategy to ensure growth and debt sustainability. A pertinent question is whether the various fiscal policies at the national levels are complements or substitutes. In this section, we consider two fiscal policy coordination plans and compare them with the discretionary home consolidation in the previous section. 
Figure 10: Fiscal policy coordination: Taylor rule regime.
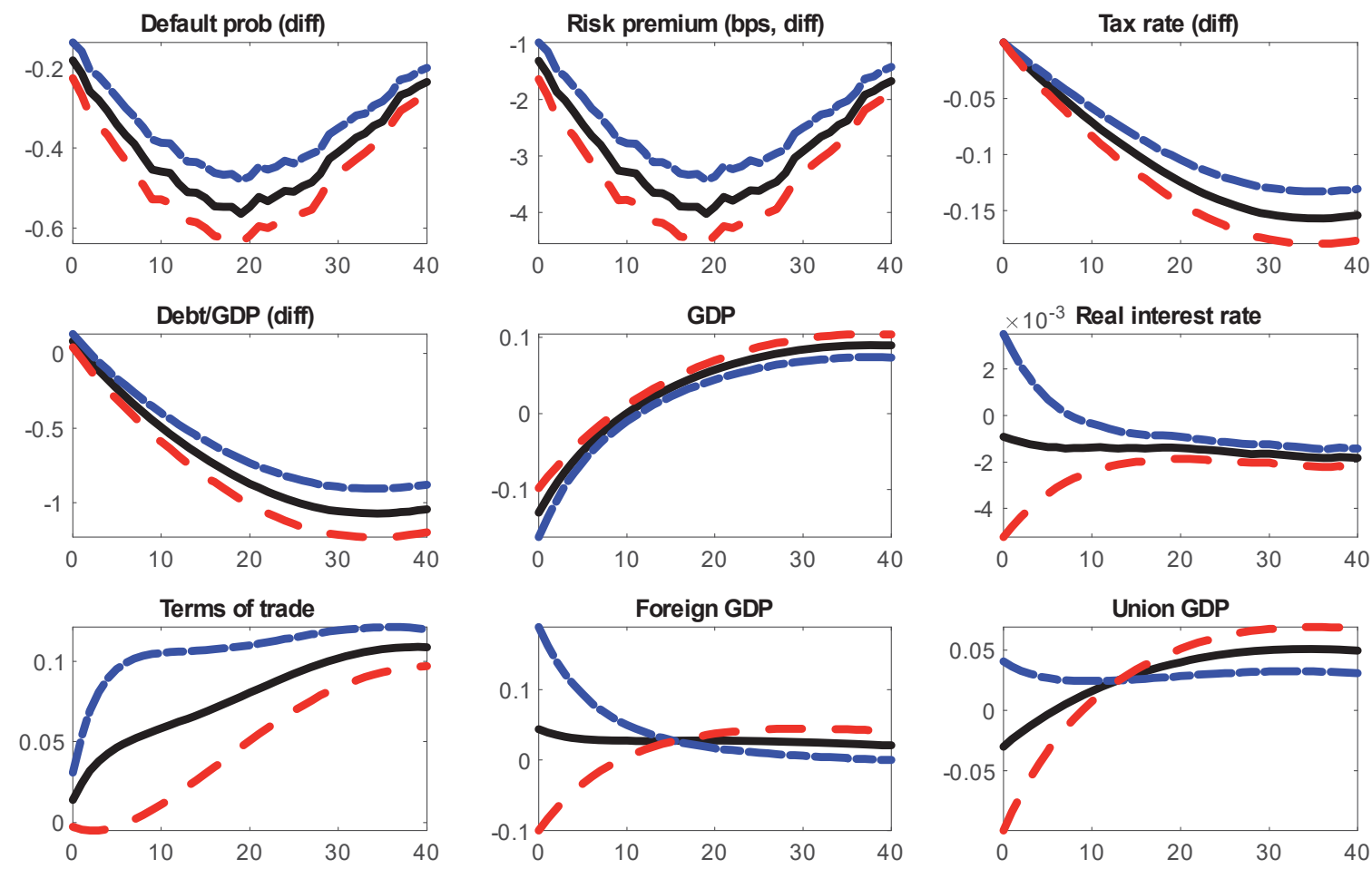

Home consolidation

Home consolidation \& Foreign expansion

-Both consolidation

Notes: See Figure 8 for units of y-axes.

Figure 10 plots the macroeconomic effects of three fiscal policy combinations: A 1 percent government spending cut in the high debt home country (solid lines), a 1 percent government spending cut in the high debt home country and a 1 percent government spending increase in the low debt foreign country (dashed lines), and a 1 percent government spending cut in both countries (dashed-dotted lines). In the short run, fiscal expansions in the foreign country increase foreign GDP and union-wide inflation rate, pushing up real interest rates in both countries. As a consequence home GDP decreases, but given the large size of the foreign country, the union GDP improves. Moreover, the higher real interest rates worsen debt sustainability in the home country, increasing default probabilities and the risk premium. This effect partially compensates the reduction of risk premium from home consolidation and lowers home GDP relative to the case without foreign fiscal expansions. After year three, when the initial positive effects on the foreign GDP fade away, the negative effects on home GDP start to dominate, and the union-wide GDP becomes lower with foreign expansion than otherwise without one. The little spillover on home activity from a foreign fiscal expansion is partly due to the weak trade channel present in this model. This could be mitigated by allowing public spending to be a basket of home and foreign goods and/or assuming that consumers derive utility from the provision of public goods, which then become complements of private consumption and thus reduce the crowding-in effects. 
On the other hand, a fiscal consolidation in both countries lowers foreign GDP in the short run but yields the highest union GDP in the long run among the three policy strategies. Foreign fiscal consolidation, although it lowers demand in the foreign country and hence its GDP, also reduces the real interest rate in the home country. Given the existing high levels of public debt in the home economy, the decrease in real debt service is not trivial. The fiscal limit distribution immediately shifts to the right, which reduces the risk premium even more. In the long run, both the home and foreign country benefit from the policy coordination of consolidation, at a cost of a significantly lower foreign GDP in the short run.

Figure 11: Fiscal policy coordination: zero lower bound regime.
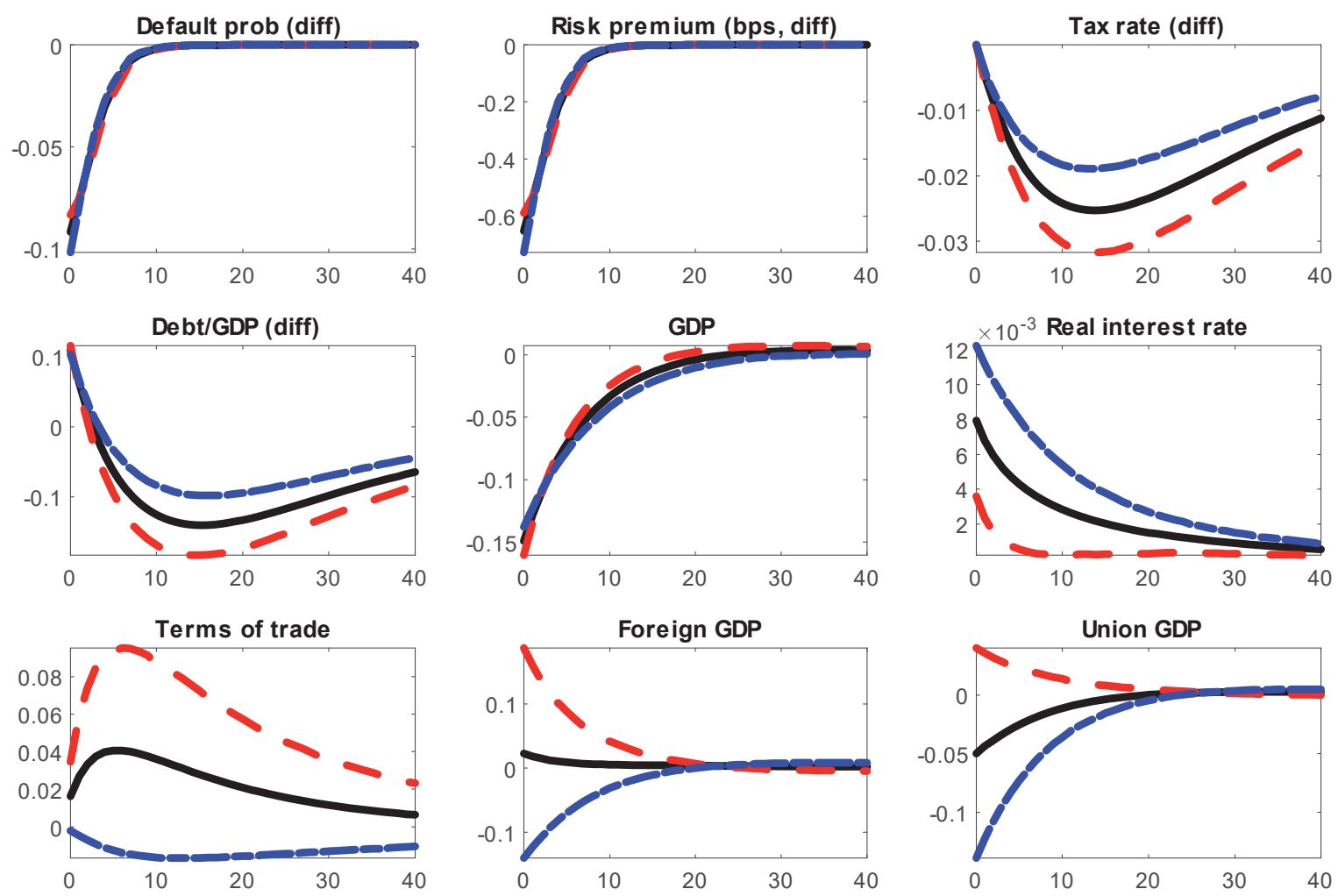

ZLB: H consolidation - ZLB: H consolidation \& F expansion

$-\infty$ ZLB: H \& F consolidation

Notes: See Figure 8 for units of y-axes.

When the ZLB is binding, the implications from policy coordination change significantly. The real interest rate channel at the ZLB, as explained earlier, works against the risk premium channel and almost offsets lower risk premium from fiscal consolidations. The maximum changes in risk premium are between 0.6 to 0.8 basis points at the ZLB regime compared to 3 to 5 basis points at the Taylor rule regime, given different policy combinations. The policy effects, as a result, are dominated by the real interest rate channel. With foreign fiscal expansion at the ZLB, the increase in the real interest rate is most muted and converges to 
zero after five quarters, producing the largest expansionary effect union wide. This result is in line with previous findings in the literature. Blanchard et al. (2017) show that a fiscal expansion by the core economies of the euro area would have a large and positive impact on periphery GDP assuming that policy rates remain low for a prolonged period. Arce et al. (2016) find that a fiscal expansion in the core aggravates the recession in the periphery, due to higher real rates, but the cross-country spillovers are reversed in a liquidity trap. Therefore, our results extend the previous findings to show that even in the presence of a fiscal limit the fiscal policy spillovers depend critically on the monetary policy regimes.

\section{Concluding remarks}

In this paper we study the effects of fiscal policy and its spillovers for countries in a monetary union with different levels of public debt. We develop a dynamic stochastic general equilibrium model of a two-country monetary union in which country members have substantially different debt to GDP ratios. These two countries are calibrated to match the characteristics of Spain and Germany respectively. Only the high-debt country (100 percent of GDP) faces some probability of default on the service of its debt. This probability is endogenous and default occurs when current outstanding real debt in period $t$ is higher than the maximum amount of public debt that the government can finance without defaulting on their financial commitments or fiscal limit. This fiscal limit is calculated as the expected discounted sum of maximum primary surplus that can be generated in the future, given the current fiscal strategy and the expected evolution of the economy. Since this evolution is uncertain this gives rise to a distribution of values of the maximum sustainable level of debt out of which a particular value is drawn as the stochastic fiscal limit.

Policy changes affect now the economy in two ways. One is the standard transmission mechanism built in the DSGE model, the other is the change in the market's expectation about future primary surplus, which has a direct effect on the fiscal limit distribution and hence on the probability of default and on the current sovereign risk premium. This adds a new channel to the macroeconomic responses to policy (or otherwise) shocks.

We find that the fiscal permanent consolidation necessary to bring a high-debt country back to more sustainable debt levels within a monetary union is very costly in terms of output loss not only for the consolidating country, but also for the other members of the union. The fact that high debt makes it more likely to hit the fiscal limit introduces an additional cost to high-debt countries in the form of a risk premium in the interest rate that affects both the government and the private sector spending decisions. In these circumstances, frontloaded (faster) public debt consolidations are still more costly than more gradual ones in terms of 
GDP and consumption loss, but this extra cost is smaller than what would be in an economy not facing a risk premium.

In normal times, when monetary policy is run according to a standard Taylor rule, transitory government spending cuts in the high-debt country enlarge the fiscal space of the economy, reduce risk premium and facilitate a faster recovery of output, as compared with what would happen in a low-debt economy. In such a case, the short-term improvement in public finances of a high-debt country reduces its risk premium on impact and thereafter, making the output costs of consolidating much smaller. Moreover, this effect may be quantitatively relevant as the long-term multipliers of government spending are greatly reduced by this risk premium channel, and may even change sign. This effect is highly non linear; it is hardly significant when the economy starts from a debt to GDP ratio below 90 percent, and increases rapidly beyond 100 percent. On the contrary, a fiscal expansion in a high debt country, even of a transitory character, in our model will significantly increase the risk-premium undoing most of the direct output gains derived from the increase in government spending.

In terms of fiscal coordination within the monetary union, the best strategy in a normal monetary regime is for both members to consolidate simultaneously since this decreases real interest rates and amplifies the reduction in risk premium in the highly-indebted country, improving union-wide output in the long run, but at the cost of lower output in the low-debt country in the short term.

On the contrary, when monetary policy is constrained at the zero lower bound, the risk premium channel arising from endogenous fiscal limits and driving all the previous results becomes muted, making the costs of consolidation very similar across the high and low debt economies within the monetary union. If monetary policy is constrained in this way the real interest rate moves in opposite direction than the inflation rate, which may offset partially or completely the response of the risk premium. In this context, the best coordination strategy is for the low-debt country to expand government spending and for the high-debt country to consolidate.

In future work we would like to explore how our results are affected under two different environments. First, what happens when some of the risk sharing mechanisms available within a monetary union and currently under discussion in the policy debate. In particular, it would be interesting to extend the model to allow for cross border purchases of sovereign debt, the introduction of a Eurobond or the creation of a fiscal capacity at the EMU level to smooth the effects of asymmetric shocks. Second, what happens when a part of government expenditure is of a productive nature and thus affects positively the supply-side of the economy. In this case, the impact on the fiscal limit from the worsening of public finances due 
to the fiscal expansion may be partially compensated by the improvement in productivity. This trade-off may change the results of the policy coordination exercises described in this paper and is a policy option currently very prominent in the debate of fiscal coordination within EMU. 


\section{References}

Aguiar, M. and G. Gropinath (2006). Defaultable debt, interest rates and the current account. Journal of International Economics 69, 64-83.

Alesina, A. and S. Ardagna (2010). Large changes in fiscal policy: Taxes versus spending. Tax Policy and the Economy 24(1), 35-68.

Alesina, A., S. Ardagna, and J. Galí (1998). Tales of fiscal adjustment. Economic Policy 13(27), 489-545.

Alvarez, L. J., E. Dhyne, M. Hoeberichts, C. Kwapil, H. Bihan, P. LÃijnnemann, F. Martins, R. Sabbatini, H. Stahl, P. Vermeulen, and J. Vilmunen (2006). Sticky prices in the euro area: A summary of new micro-evidence. Journal of the European Economic Association 4(3), 575-584.

Arce, O., S. Hurtado, and C. Thomas (2016). Policy spillovers and synergies in a monetary union. International Journal of Central Banking 12(3), 219-277.

Arellano, C. (2008). Default risk and income fluctuations in emerging economies. American Economic Review 98(3), 690-712.

Ascari, G. and L. Rossi (2012). Trend inflation and firms price-setting: Rotemberg versus calvo. The Economic Journal 122(563), 1115-1141.

Batini, N., G. Melina, and S. Villa (2018). Fiscal buffers, private debt, and recession: The good, the bad and the ugly. Journal of Macroeconomics.

Battistini, N., G. Callegari, and L. Zavalloni (2019). Dynamic fiscal limits and monetary-fiscal policy interactions. ECBF Working Paper No. 2268.

Benigno, G. and P. Benigno (2006). Designing targeting rules for international monetary policy cooperation. Journal of Monetary Economics 53(3), 473-506.

Bi, H. (2012). Sovereign default risk premia, fiscal limits, and fiscal policy. European Economic Review 56 (3), 389-410.

Bi, H., E. M. Leeper, and C. Leith (2018). Sovereign default and monetary policy tradeoffs. International Journal of Central Banking. forthcoming.

Bi, H., W. Shen, and S.-C. S. Yang (2016). Fiscal limits in developing countries: A DSGE approach. Journal of Macroeconomics 49, 119-130.

Blanchard, O., C. J. Erceg, and J. Linde (2017). Jump-starting the euro-area recovery: Would a rise in core fiscal spending help the periphery? NBER Macroeconomics Annual 31(1), 103-182. 
Blanchard, O. J. (2019). Public debt and low interest rates. American Economic Review 109(4), $1197-1229$.

Chari, V. V., A. Dovis, and P. J. Kehoe (2019). Rethinking optimal currency areas. Journal of Monetary Economics.

Coleman, II, W. J. (1991). Equilibrium in a production economy with an income tax. Econometrica 59(4), 1091-1104.

Corsetti, G., K. Kuester, A. Meier, and G. J. Muller (2013). Sovereign risk, fiscal policy, and macroeconomic stability. The Economic Journal 123(566), 99-132.

Corsetti, G., K. Kuester, A. Meier, and G. J. Muller (2014). Sovereign risk and belief-driven fluctuations in the euro area. Journal of Monetary Economics 61, 53-73.

Corsetti, G., A. Meier, and G. J. Muller (2010). Cross-border spillovers from fiscal stimulus. International Journal of Central Banking 6(1), 5-37.

Daniel, B. C. and C. Shiamptanis (2012). Fiscal risk in a monetary union. European Economic Review 56(6), 1289-1309.

Davig, T. (2004). Regime-switching debt and taxation. Journal of Monetary Economics 51(4), 837-859.

Davig, T., E. M. Leeper, and T. B. Walker (2010). Unfunded liabilities and uncertain fiscal financing. Journal of Monetary Economics 57(5), 600-619.

Dovis, A. (2019). Efficient sovereign default. The Review of Economic Studies 86(1), 282-312.

Eaton, J. and M. Gersovitz (1981). Debt with potential repudiation: Theoretical and empirical analysis. Review of Economic Studies 48(2), 289-309.

European Commission (2018). Taxation trends in the European Union. European Union.

Fabiani, S., M. Druant, I. Hernando, C. Kwapil, B. Landau, C. Loupias, F. Martins, T. Matha, R. Sabbatini, H. Stahl, and A. C. J. Stokman (2005). The pricing behaviour of italian firms: new survey evidence on price stickiness. ECB working paper No. 535, October 2005.

Farhi, E. and I. Werning (2016). Fiscal Multipliers: Liquidity Traps and Currency Unions, Volume 2, Book section 31, pp. 2417-2492. Elsevier.

Gadatsch, N., K. Hauzenberger, and N. Stähler (2015). Germany and the rest of euro area fiscal policy during the crisis. Discussion Paper No. 05/2015, Deutsche Bundesbank.

Garcia-Cicco, J., R. Pancrazi, and M. Uribe (2010). Realbusiness cycles inemerging countries? American Economic Review 100(5), 2510-31. 
Giavazzi, F. and M. Pagano (1990). Can severe fiscal contractions be expansionary? tales of two small european countries. NBER Macroeconomics Annual 5, 75-111.

Gil, M., J. J. Pérez, and A. Urtasun (2017). Macroeconomic uncertainty: measurement and impact on the Spanish economy. Economic Bulletin. Banco de España.

Mendoza, E. G. and V. Z. Yue (2012). A general equilibrium model of sovereign default and business cycles. The Quarterly Journal of Economics 127(2), 889-946.

Polito, V. and M. Wickens (2015). Sovereign credit ratings in the european union: A model-based fiscal analysis. European Economic Review 78, 220-247.

Richter, A. and N. Throckmorton (2015). The zero lower bound: frequency, duration, and numerical convergence. The B.E. Journal of Macroeconomics 15(1), 157.

Rotemberg, J. J. (1982). Sticky prices in the United States. Journal of Political Economy 90(6), 1187-1211.

Schmitt-Grohe, S. and M. Uribe (2007). Optimal simple and implementable monetary and fiscal rules. Journal of Monetary Economics 54(6), 1702-1725.

Sturzenegger, F. and J. Zettelmeyer (2008). Haircuts: Estimating investor losses in sovereign debt restructurings, 1998-2005. Journal of International Money and Finance 27(5), 780-805.

Trabandt, M. and H. Uhlig (2011). The laffer curve revisited. Journal of Monetary Economics 58(4), $305-327$.

Uribe, M. and V. Z. Yue (2006). Country spreads and emerging countries: Who drives whom? Journal of International Economics $69(1), 6-36$.

Vermeulen, P., D. A. Dias, M. Dossche, E. Gautier, I. Hernando, R. Sabbatini, and H. Stahl (2012). Price setting in the euro area: Some stylized facts from individual producer price data. Journal of Money, Credit and Banking $44(8), 1631-1650$.

Yue, V. Z. (2010). Sovereign default and debt renegotiation. Journal of International Economics 80, $176-187$. 


\section{Appendix A Equilibrium}

The equilibrium consists of 35 equations (16 for the home country, 14 for the foreign country and 5 are common), to solve for 35 variables $\left(\lambda_{t}, c_{t}, n_{t}, w_{t}, \delta_{t}, R_{t}, \tau_{t}, \pi_{t}, \pi_{H, t}, m c_{t}, y_{t}, b_{t}\right.$, $T_{t}, c_{M U, t}^{H}, \Upsilon_{t}, g_{t}$ for the home country, $\lambda_{t}^{*}, c_{t}^{*}, n_{t}^{*}, w_{t}^{*}, \tau_{t}^{*}, \pi_{t}^{*}, \pi_{F, t}, m c_{t}^{*}, y_{t}^{*}, b_{t}^{*}, T_{t}^{*}, c_{M U, t}^{F}, \Upsilon_{t}^{*}$, $g_{t}^{*}$ for the foreign country and $\left.t_{t}, R E R_{t}, \pi_{M U, t}, y_{M U, t}, R_{t}^{f}\right)$ for the union.

Home equations

$$
\begin{gathered}
\lambda_{t}=c_{t}^{-\sigma} \\
n_{t}^{\varphi}=\lambda_{t}\left(1-\tau_{t}\right) w_{t}
\end{gathered}
$$

Since we have default, we need both the Euler equation under default and under no default to evaluate the expectation about future defaults

$$
\begin{aligned}
& \lambda_{t}=\beta R_{t}^{f} E_{t} \frac{\lambda_{t+1}}{\pi_{t+1}} \\
& \lambda_{t}=\beta R_{t} E_{t} \frac{\left(1-\delta_{t+1}\right) \lambda_{t+1}}{\pi_{t+1}} \\
& \delta_{t}=\left\{\begin{array}{lll}
0 & \text { if } & b_{t-1}<\mathcal{B}^{H}\left(\mathcal{S}_{t}\right) \\
\delta & \text { if } & b_{t-1} \geq \mathcal{B}^{H}\left(\mathcal{S}_{t}\right)
\end{array}\right. \\
& \pi_{t}=\pi_{H, t}^{\eta} \pi_{F, t}^{1-\eta} \\
& m c_{t}=\operatorname{tot}_{t}^{1-\eta} \frac{w_{t}}{a} \\
& \psi\left(\frac{\pi_{H, t}}{\pi}-1\right) \frac{\pi_{H, t}}{\pi}=(1-\theta)+\theta m c_{t}+\psi \beta E_{t}\left(\frac{\lambda_{t+1}}{\lambda_{t}}\left[\frac{\pi_{H, t+1}}{\pi}-1\right]\left(\frac{y_{t+1} \pi_{H, t+1}}{y_{t} \pi}\right)\right) \\
& {\left[1-\frac{\psi}{2}\left(\frac{\pi_{H, t}}{\pi}-1\right)^{2}\right] y_{t}=\operatorname{tot}_{t}^{1-\eta} c_{M U, t}^{H}+g_{t}} \\
& c_{M U, t}^{H}=\eta c_{t}+\eta^{*} \frac{1-s}{s} c_{t}^{*} \\
& y_{t}=a n_{t} \\
& \Upsilon_{t}=\left[1-m c_{t}-\frac{\psi}{2}\left(\frac{\pi_{H, t}}{\pi}-1\right)^{2}\right] y_{t}
\end{aligned}
$$




$$
\begin{gathered}
\frac{b_{t}}{R_{t}}+\frac{T_{t}-g_{t}}{t o t_{t}^{1-\eta}}=\frac{\left(1-\delta_{t}\right) b_{t-1}}{\pi_{t}} \\
T_{t}=\left[1-\frac{\psi}{2}\left(\frac{\pi_{H, t}}{\pi}-1\right)^{2}\right] \tau_{t} y_{t} \\
\tau_{t}=\tau+\gamma_{b}\left(b_{t-1}-b\right) \\
\ln \frac{g_{t}}{g}=\rho^{g} \ln \frac{g_{t-1}}{g}+\varepsilon_{t}^{g}
\end{gathered}
$$

Foreign equations

$$
\begin{gathered}
\lambda_{t}^{*}=\left(c_{t}^{*}\right)^{-\sigma} \\
\left(n_{t}^{*}\right)^{\varphi}=\lambda_{t}^{*}\left(1-\tau_{t}^{*}\right) w_{t}^{*}
\end{gathered}
$$

In the full model, if there is no default in either country, the risky and risk free rates are identical and we can use the $R E R_{t}$ expression for foreign consumption. If instead home country sovereign debt is subject to default, while foreign country's sovereign debt is not, then the rate of return in foreign is equal to the risk-free rate, but we have to use the foreign Euler equation to solve the model.

no default in the model (both home and foreign): $\left(\frac{c_{t}}{c_{t}^{*}}\right)^{\sigma}=R E R_{t}=t o t_{t}^{\eta-\eta^{*}}$

$$
\begin{gathered}
\text { default in home but no default in foreign: } \lambda_{t}^{*}=\beta R_{t}^{f} E_{t} \frac{\lambda_{t+1}^{*}}{\pi_{t+1}^{*}} \\
\pi_{t}^{*}=\pi_{H, t}^{\eta^{*}} \pi_{F, t}^{1-\eta^{*}} \\
m c_{t}^{*}=t o t_{t}^{-\eta^{*}} \frac{w_{t}^{*}}{a^{*}} \\
\psi\left(\frac{\pi_{F, t}}{\pi^{*}}-1\right) \frac{\pi_{F, t}}{\pi^{*}}=(1-\theta)+\theta m c_{t}^{*}+\psi \beta E_{t}\left(\frac{\lambda_{t+1}^{*}}{\lambda_{t}^{*}}\left(\frac{\pi_{F, t+1}}{\pi^{*}}-1\right) \frac{y_{t+1}^{*} \pi_{F, t+1}}{y_{t}^{*} \pi^{*}}\right) \\
{\left[1-\frac{\psi}{2}\left(\frac{\pi_{F, t}}{\pi^{*}}-1\right)^{2}\right] y_{t}^{*}=t o t_{t}^{-\eta^{*}} c_{M U, t}^{F}+g_{t}^{*}} \\
c_{M U, t}^{F}=\frac{s(1-\eta)}{1-s} c_{t}+\left(1-\eta^{*}\right) c_{t}^{*}
\end{gathered}
$$




$$
\begin{gathered}
y_{t}^{*}=a^{*} n_{t}^{*} \\
\Upsilon_{t}^{*}=\left[1-m c_{t}^{*}-\frac{\psi}{2}\left(\frac{\pi_{F, t}}{\pi^{*}}-1\right)^{2}\right] y_{t}^{*} \\
\frac{b_{t}^{*}}{R_{t}^{f}}+t o t_{t}^{\eta^{*}}\left(T_{t}^{*}-g_{t}^{*}\right)=\frac{b_{t-1}^{*}}{\pi_{t}^{*}} \\
T_{t}^{*}=\left[1-\frac{\psi}{2}\left(\frac{\pi_{F, t}}{\pi^{*}}-1\right)^{2}\right] \tau_{t}^{*} y_{t}^{*} \\
\tau_{t}^{*}=\tau^{*}+\gamma_{b}\left(b_{t-1}^{*}-b^{*}\right) \\
\ln \frac{g_{t}^{*}}{g^{*}}=\rho^{g} \ln \frac{g_{t-1}^{*}}{g^{*}}+\varepsilon_{t}^{g^{*}}
\end{gathered}
$$

Union wide equations

$$
\begin{aligned}
& \text { tot }_{t}=\operatorname{tot}_{t-1} \frac{\pi_{F, t}}{\pi_{H, t}} \\
& R_{t}= \begin{cases}R+\alpha_{\pi}\left(\pi_{M U, t}-\pi_{M U}\right), & \text { if } s_{t}^{R}=1 \\
1, & \text { if } s_{t}^{R}=2\end{cases} \\
& y_{M U, t}=s y_{t}+(1-s) y_{t}^{*} \\
& \pi_{M U, t}=s \pi_{t}+(1-s) \pi_{t}^{*} \\
& R E R_{t}=t_{o t}^{\eta-\eta^{*}}
\end{aligned}
$$

\section{Appendix B The Numerical Solution Method}

\section{Appendix B.1 Solving the fiscal limit}

This appendix describes procedures in simulating fiscal limit distributions. First, derive the expression of the fiscal limit as (31). Second, replace the fiscal rules (A.15) and (A.30) with the maximum tax rate $\tau^{\max }$ and $\tau^{* \max }$ and solve the full model (without default) non-linearly evaluated at the maximum tax rate.

When solving the nonlinear model without default, the state space is $\mathcal{S}_{t}=\left\{g_{t}, g_{t}^{*}\right.$, tot $\left._{t-1}, s_{t}^{R}\right\}$, depending on the number of exogenous shocks we consider to build the fiscal limit. Since the model without default has three expectation terms in equations (Euler equation of home 
country (A.3) $)^{15}$, Phillips curve of home (A.8) and foreign (A.23) we need three decision rules. It can be shown that these three equations can be written as a function of only three variables: $n_{t}, \pi_{H, t}$ and $\pi_{F, t}$. Therefore, the decision rule for labor in home country is $n_{t}^{\max }=f^{n}\left(\mathcal{S}_{t}\right)$, the rule for inflation of the home goods is $\pi_{H, t}^{\max }=f^{\pi_{H}}\left(\mathcal{S}_{t}\right)$, and the rule for inflation of the foreign goods is $\pi_{F, t}^{\max }=f^{\pi_{F}}\left(\mathcal{S}_{t}\right)$.

From the converged rules for $f^{n}(\cdot), f^{\pi_{H}}(\cdot)$, and $f^{\pi_{F}}(\cdot)$, we derive the rules for the remaining variables determining the fiscal limit $T_{t}^{\max }=f^{\mathcal{T}}\left(\mathcal{S}_{t}\right), T_{t}^{* \max }=f^{\mathcal{T} *}\left(\mathcal{S}_{t}\right), \lambda_{t}^{\max }=f^{\lambda}\left(\mathcal{S}_{t}\right)$, $\lambda_{t}^{* \max }=f^{\lambda *}\left(\mathcal{S}_{t}\right)$, and tot $_{t}^{\max }=f^{t o t}\left(\mathcal{S}_{t}\right)$, which are consistent with the optimization conditions from the household's and the firms' problems.

To solve the model we proceed as follows:

1. Define the grid points by discretizing the state space (over the 4 dimensions). Make initial guesses for $f_{0}^{n}, f_{0}^{\pi_{H}}$, and $f_{0}^{\pi_{F}}$ over the state space.

2. Under the maximum tax rates $\left(\tau^{\max }, \tau^{* \max }\right)$, at each grid point, solve the nonlinear model using the given rules $f_{i-1}^{n}, f_{i-1}^{\pi_{H}}$, and $f_{i-1}^{\pi_{F}}$, and obtain the updated rules $f_{i}^{n}, f_{i}^{\pi_{H}}$, and $f_{i}^{\pi_{F}}$. Specifically:

(a) derive $\pi_{t}$ and tot $t_{t}$ in terms of $\pi_{H, t}$ and $\pi_{F, t}$ using (A.6) and (A.32). Derive $y_{t}$ in terms of $a$ and $n_{t}$ using (A.11).

(b) Compute $c_{M U, t}^{H}$ from (A.9). Given (A.20) and (A.10), we have $c_{t}=\frac{c_{M U, t}^{H}}{\eta+\eta^{*} \frac{1-s}{s} t o t_{t}^{\eta^{*}-\eta}}$ and $c_{t}^{*}=c_{t} t o t_{t}^{\eta^{*}-\eta}$. Then $\lambda_{t}=\left(c_{t}\right)^{-\sigma}$ and $\lambda_{t}^{*}=\left(c_{t}^{*}\right)^{-\sigma}$.

(c) Compute $w_{t}, m c_{t}$, and $T_{t}$ using (A.2), (A.7), and (A.14).

(d) From (A.24), (A.26), (A.29), (A.18), and (A.22), we can derive $c_{M U, t}^{F}, y_{t}^{*}, n_{t}^{*}, T_{t}^{*}$, $w_{t}^{*}$, and $m c_{t}^{*}$.

(e) Derive $\pi_{t}^{*}$ using (A.21). Given $\pi_{t}, \pi_{t}^{*}, y_{t}, y_{t}^{*}, s_{t}^{R}$, and (A.34), (A.35), obtain the nominal interest rate $R_{t}$ from equation (A.33).

(f) Use linear interpolation to obtain $f_{i-1}^{n}\left(\mathcal{S}_{t+1}\right), f_{i-1}^{\pi_{H}}\left(\mathcal{S}_{t+1}\right)$, and $f_{i-1}^{\pi_{F}}\left(\mathcal{S}_{t+1}\right)$, where the state vector is $\mathcal{S}_{t+1}=\left(g_{t+1}, g_{t+1}^{*}, t_{t} t_{t}, s_{t+1}^{R}\right)$. This is necessary because the policy function at time $t$ is a mapping from a value of the state variables on the grid points $\left(g_{t}, g_{t}^{*}\right.$, tot $\left._{t-1}, s_{t}^{R}\right)$ to endogenous variables $n_{t}, \pi_{H, t}, \pi_{F, t}$, but the policy function at time $t+1$ that evaluates $n_{t+1}, \pi_{H, t+1}, \pi_{F, t+1}$ may correspond to a value of the state variables in between two grid points, and therefore, to calculate it we have to linearly interpolate those two points. Then, follow the above steps to solve $\lambda_{t+1}$, $\lambda_{t+1}^{*}, y_{t+1}, y_{t+1}^{*}, \pi_{t+1}, \pi_{t+1}^{*}$.

\footnotetext{
${ }^{15}$ We do not have an expectation term in the foreign Euler equation because in the model without risk we can use instead equation (A.20).
} 
(g) Update the decision rules $f_{i}^{n}, f_{i}^{\pi_{H}}$, and $f_{i}^{\pi_{F}}$, using (A.3), (A.8), and (A.23). The integral in expectation terms is evaluated using numerical quadrature.

3. Check convergence of the decision rules. If $\left|f_{i}^{n}-f_{i-1}^{n}\right|,\left|f_{i}^{\pi_{H}}-f_{i-1}^{\pi_{H}}\right|$, or $\left|f_{i}^{\pi_{F}}-f_{i-1}^{\pi_{F}}\right|$ is above the desired tolerance (set to $1 e-6$ ), go back to step 2 . Otherwise, $f_{i}^{n}, f_{i}^{\pi_{H}}$, and $f_{i}^{\pi_{F}}$ are the decision rules.

4. Use the converged rules- $f^{n}, f^{\pi_{H}}$, and $f^{\pi_{H}}$ - to compute the decision rules for $f_{i}^{\mathcal{T}}, f_{i}^{\mathcal{T} *}$, $f_{i}^{\lambda}, f_{i}^{\lambda *}$, and $f_{i}^{t o t}$.

Since the maximum tax rate is quite far away from the average tax rate, we may need to solve the non-linear model increasing the tax rate gradually from the calibration until we reach the maximum level.

Using the maximum tax revenue $f^{\mathcal{T}}(\cdot), f^{\mathcal{T} *}(\cdot), f^{\lambda}(\cdot), f^{\lambda *}(\cdot)$, and $f^{t o t}(\cdot)$, the distribution of fiscal limits is obtained using Markov Chain Monte Carlo simulations. Now, since we want to obtain the whole distribution, we evaluate expressions (31) without taking expectations. To proceed,

1. For each simulation $j$, we randomly draw sequences of the exogenous shocks for government spending shocks in the home country $\left(\varepsilon_{t+i}^{g, j}\right)$, and government spending shocks in the foreign country $\left(\varepsilon_{t+i}^{g * j}\right)$ for 1000 periods, $i=\{1,2,3, \ldots 1000\}$, conditional on the starting state $\mathcal{S}_{t}=\left\{g_{t}, g_{t}^{*}\right.$, tot $\left._{t-1}, s_{t}^{R}\right\}$. If the simulation starts from the steady state, we call it the unconditional fiscal limit, otherwise it is the conditional one. At each period $i$, we obtain $T_{t+i}^{\max , j}, T_{t+i}^{* \max , j}, \lambda_{t+i}^{\max , j}, \lambda_{t+i}^{* \max , j}$, and $t o t_{t+i}^{\max , j},(i=1, \ldots, 1000)$ by interpolating on the decision rules $f^{\mathcal{T}}(\cdot), f^{\mathcal{T} *}(\cdot), f^{\lambda}(\cdot), f^{\lambda *}(\cdot)$, and $f^{\text {tot }}(\cdot)$. This is necessary because the policy function is a mapping from a value of the state variables on the grid points $\left(g_{t}, g_{t}^{*}\right.$, tot $\left._{t-1}, s_{t}^{R}\right)$ to endogenous variables $\mathcal{T}_{t}, \mathcal{T}_{t}^{*}, \lambda_{t}, \lambda_{t}^{*}$, and tot $_{t}$, but following the stochastic processes, the realizations of the state variables may fall in between two grid points, and therefore, to calculate it we have to linearly interpolate those two points. Then, the fiscal limit for simulation $j$ is computed (without taking expectations), conditional on $\mathcal{S}_{t}$ and particular sequences of shocks,

2. Repeat the simulation 50,000 times $(j=\{1, \ldots, 50,000\})$ to have $\left\{\mathcal{B}^{\max , j}\left(\mathcal{S}_{t}\right)\right\}_{j=1}^{50000}$, which form the distribution of $\mathcal{B}^{H}\left(\mathcal{S}_{t}\right)$.

\section{Appendix B.2 Solving full model}

When solving the nonlinear model with default, the state space is $\mathcal{S}_{t}=\left\{\left(1-\delta_{t}\right) b_{t-1}, b_{t-1}^{*}, g_{t}, g_{t}^{*}, t_{t-1}, s_{t}^{R}\right\}$. In this model there are 5 expectation terms in equations (Euler equation of home country 
(A.3) and (A.4), Euler equation of the foreign country (A.20) ${ }^{16}$, Phillips curve of home (A.8) and foreign (A.23)) and thus we need five decision rules. ${ }^{17}$ It can be shown that these five equations can be written as a function of only five variables: $b_{t}, c_{t}, c_{t}^{*}, \pi_{H, t}$ and $\pi_{F, t}$. Define the decision rules for the end-of-period home government bond as $b_{t}=f^{b}\left(\mathcal{S}_{t}\right)$, consumption in home country as $c_{t}=f^{c}\left(\mathcal{S}_{t}\right)$, consumption in foreign country as $c_{t}^{*}=f^{c^{*}}\left(\mathcal{S}_{t}\right)$, inflation of the home goods is $\pi_{H, t}=f^{\pi_{H}}\left(\mathcal{S}_{t}\right)$, and inflation of the foreign goods is $\pi_{F, t}=f^{\pi_{F}}\left(\mathcal{S}_{t}\right)$. The decision rules are solved as follows:

1. Define the grid points by discretizing the state space (over the 6 dimensions). Make initial guesses for $f_{0}^{b}, f_{0}^{c}, f_{0}^{c^{*}}, f_{0}^{\pi_{H}}$, and $f_{0}^{\pi_{F}}$ over the state space.

2. At each grid point, solve the nonlinear model and obtain the updated rules $f_{i}^{b}, f_{i}^{c}, f_{i}^{c^{*}}$, $f_{i}^{\pi_{H}}$, and $f_{i}^{\pi_{F}}$ using the given rules $f_{i-1}^{b}, f_{i-1}^{c}, f_{i-1}^{c^{*}}, f_{i-1}^{\pi_{H}}$, and $f_{i-1}^{\pi_{F}}$ :

(a) Derive $\pi_{t}$ and tot $_{t}$ in terms of $\pi_{H, t}$ and $\pi_{F, t}$ using (A.6) and (A.32). Derive RER and $\tau_{t}$ using (A.36) and (A.15).

(b) Compute $c_{M U, t}^{H}$ from (A.10). Then $y_{t}$ can be obtained from (A.9), and $n_{t}$ is given by (A.11).

(c) Compute $w_{t}, m c_{t}$, and $T_{t}$ using (A.2), (A.7), and (A.14).

(d) From (A.24), (A.26), (A.30), (A.29), (A.18), and (A.22), we can derive $c_{M U, t}^{F}, y_{t}^{*}$, $n_{t}^{*}, \tau_{t}^{*}, T_{t}^{*}, w_{t}^{*}$, and $m c_{t}^{*}$.

(e) Derive $\pi_{t}^{*}$ using (A.21). Given $\pi_{t}, \pi_{t}^{*}, y_{t}, y_{t}^{*}, s_{t}^{R}$, and (A.34), (A.35), obtain the nominal risk free interest rate $R_{t}^{f}$ from equation (A.33).

(f) Compute $b_{t}^{*}$ using (A.28) and the risky rate $R_{t}$ using (A.13).

(g) Use linear interpolation to obtain $f_{i-1}^{b}\left(\mathcal{S}_{t+1}\right), f_{i-1}^{c}\left(\mathcal{S}_{t+1}\right), f_{i-1}^{c^{*}}\left(\mathcal{S}_{t+1}\right), f_{i-1}^{\pi_{H}}\left(\mathcal{S}_{t+1}\right)$ and $f_{i-1}^{\pi_{F}}\left(\mathcal{S}_{t+1}\right)$, where $\mathcal{S}_{t+1}=\left(\left(1-\delta_{t+1}\right) b_{t}, b_{t}^{*}, g_{t+1}, g_{t+1}^{*}, t_{t}, s_{t+1}^{R}\right)$. Then follow the above steps to solve $\lambda_{t+1}, \lambda_{t+1}^{*}, y_{t+1}, y_{t+1}^{*}, \pi_{t+1}, \pi_{t+1}^{*}$.

(h) Update the decision rules $f_{i}^{b}, f_{i}^{c}, f_{i}^{c^{*}}, f_{i}^{\pi_{H}}$, and $f_{i}^{\pi_{F}}$, using (A.3), (A.4), (A.8), (A.20), and (A.23).

3. Check convergence of the decision rules. If $\left|f_{i}^{b}-f_{i-1}^{b}\right|$, or $\left|f_{i}^{c}-f_{i-1}^{c}\right|$, or $\left|f_{i}^{c^{*}}-f_{i-1}^{c^{*}}\right|$, or $\left|f_{i}^{\pi_{H}}-f_{i-1}^{\pi_{H}}\right|$, or $\left|f_{i}^{\pi_{F}}-f_{i-1}^{\pi_{F}}\right|$ are above the desired tolerance (set to $1 e-6$ ), go back to step 2; otherwise, $f_{i}^{b}, f_{i}^{c}, f_{i}^{c^{*}}, f_{i}^{\pi_{H}}$, and $f_{i}^{\pi_{F}}$ are the decision rules.

\footnotetext{
${ }^{16}$ Since we have assumed that the foreign country is Germany, we do not need to have default in that economy, and we have replaced the Foreign Euler equation with (A.20).

${ }^{17}$ If we consider two countries which are potentially close to their fiscal limits, then we would need to include the Foreign Euler equation and the interest rate on foreign sovereign bonds $\left(R_{t}^{*}\right)$ and we would have an additional expectation term and an additional decision rule for $n_{t}^{*}$.
} 


\section{BANCO DE ESPAÑA PUBLICATIONS}

\section{WORKING PAPERS}

1840 ALESSIO MORO and OMAR RACHEDI: The changing structure of government consumption spending.

1841 GERGELY GANICS, ATSUSHI INOUE and BARBARA ROSSI: Confidence intervals for bias and size distortion in IV and local projections - IV models.

1842 MARÍA GIL, JAVIER J. PÉREZ, A. JESÚS SÁNCHEZ and ALBERTO URTASUN: Nowcasting private consumption: traditional indicators, uncertainty measures, credit cards and some internet data.

1843 MATÍAS LAMAS and JAVIER MENCÍA: What drives sovereign debt portfolios of banks in a crisis context?

1844 MIGUEL ALMUNIA, POL ANTRÀS, DAVID LÓPEZ-RODRÍGUEZ and EDUARDO MORALES: Venting out: exports during a domestic slump.

1845 LUCA FORNARO and FEDERICA ROMEl: The paradox of global thrift.

1846 JUAN S. MORA-SANGUINETTI and MARTA MARTÍNEZ-MATUTE: An economic analysis of court fees: evidence from the Spanish civil jurisdiction.

1847 MIKEL BEDAYO, ÁNGEL ESTRADA and JESÚS SAURINA: Bank capital, lending booms, and busts. Evidence from Spain in the last 150 years.

1848 DANIEL DEJUÁN and CORINNA GHIRELLI: Policy uncertainty and investment in Spain.

1849 CRISTINA BARCELÓ and ERNESTO VILLANUEVA: The risk of job loss, household formation and housing demand: evidence from differences in severance payments.

1850 FEDERICO TAGLIATI: Welfare effects of an in-kind transfer program: evidence from Mexico.

1851 ÓSCAR ARCE, GALO NUÑO, DOMINIK THALER and CARLOS THOMAS: A large central bank balance sheet? Floor vs corridor systems in a New Keynesian environment.

1901 EDUARDO GUTIÉRREZ and ENRIQUE MORAL-BENITO: Trade and credit: revisiting the evidence.

1902 LAURENT CAVENAILE and PAU ROLDAN: Advertising, innovation and economic growth.

1903 DESISLAVA C. ANDREEVA and MIGUEL GARCÍA-POSADA: The impact of the ECB's targeted long-term refinancing operations on banks' lending policies: the role of competition.

1904 ANDREA ALBANESE, CORINNA GHIRELLI and MATTEO PICCHIO: Timed to say goodbye: does unemployment benefit eligibility affect worker layoffs?

1905 CORINNA GHIRELLI, MARÍA GIL, JAVIER J. PÉREZ and ALBERTO URTASUN: Measuring economic and economic policy uncertainty, and their macroeconomic effects: the case of Spain.

1906 CORINNA GHIRELLI, JAVIER J. PÉREZ and ALBERTO URTASUN: A new economic policy uncertainty index for Spain.

1907 ESTEBAN GARCÍA-MIRALLES, NEZIH GUNER and ROBERTO RAMOS: The Spanish personal income tax: facts and parametric estimates.

1908 SERGIO MAYORDOMO and OMAR RACHEDI: The China syndrome affects banks: the credit supply channel of foreign import competition.

1909 MÓNICA CORREA-LÓPEZ, MATÍAS PACCE and KATHI SCHLEPPER: Exploring trend inflation dynamics in Euro Area countries.

1910 JAMES COSTAIN, ANTON NAKOV and BORJA PETIT: Monetary policy implications of state-dependent prices and wages.

1911 JAMES CLOYNE, CLODOMIRO FERREIRA, MAREN FROEMEL and PAOLO SURICO: Monetary policy, corporate finance and investment.

1912 CHRISTIAN CASTRO and JORGE E. GALÁN: Drivers of productivity in the Spanish banking sector: recent evidence.

1913 SUSANA PÁRRAGA RODRÍGUEZ: The effects of pension-related policies on household spending.

1914 MÁXIMO CAMACHO, MARÍA DOLORES GADEA and ANA GÓMEZ LOSCOS: A new approach to dating the reference cycle.

1915 LAURA HOSPIDO, LUC LAEVEN and ANA LAMO: The gender promotion gap: evidence from Central Banking.

1916 PABLO AGUILAR, STEPHAN FAHR, EDDIE GERBA and SAMUEL HURTADO: Quest for robust optimal macroprudential policy.

1917 CARMEN BROTO and MATÍAS LAMAS: Is market liquidity less resilient after the financial crisis? Evidence for US treasuries.

1918 LAURA HOSPIDO and CARLOS SANZ: Gender Gaps in the Evaluation of Research: Evidence from Submissions to Economics Conferences.

1919 SAKI BIGIO, GALO NUÑO and JUAN PASSADORE: A framework for debt-maturity management.

1920 LUIS J. ÁLVAREZ, MARÍA DOLORES GADEA and ANA GÓMEZ-LOSCOS: Inflation interdependence in advanced economies. 
1921 DIEGO BODAS, JUAN R. GARCÍA LÓPEZ, JUAN MURILLO ARIAS, MATÍAS J. PACCE, TOMASA RODRIGO LÓPEZ, JUAN DE DIOS ROMERO PALOP, PEP RUIZ DE AGUIRRE, CAMILO A. ULLOA and HERIBERT VALERO LAPAZ: Measuring retail trade using card transactional data.

1922 MARIO ALLOZA and CARLOS SANZ: Jobs multipliers: evidence from a large fiscal stimulus in Spain.

1923 KATARZYNA BUDNIK, MASSIMILIANO AFFINITO, GAIA BARBIC, SAIFFEDINE BEN HADJ, ÉDOUARD CHRÉTIEN, HANS DEWACHTER, CLARA ISABEL GONZÁLEZ, JENNY HU, LAURI JANTUNEN, RAMONA JIMBOREAN, OTSO MANNINEN, RICARDO MARTINHO, JAVIER MENCÍA, ELENA MOUSARRI, LAURYNAS NARUŠEVIČIUS, GIULIO NICOLETTI, MICHAEL O'GRADY, SELCUK OZSAHIN, ANA REGINA PEREIRA, JAIRO RIVERA-ROZO, CONSTANTINOS TRIKOUPIS, FABRIZIO VENDITTI and SOFÍA VELASCO: The benefits and costs of adjusting bank capitalisation: evidence from Euro Area countries.

1924 MIGUEL ALMUNIA and DAVID LÓPEZ-RODRÍGUEZ: The elasticity of taxable income in Spain: 1999-2014.

1925 DANILO LEIVA-LEON and LORENZO DUCTOR: Fluctuations in global macro volatility.

1926 JEF BOECKX, MAARTEN DOSSCHE, ALESSANDRO GALESI, BORIS HOFMANN and GERT PEERSMAN: Do SVARs with sign restrictions not identify unconventional monetary policy shocks?

1927 DANIEL DEJUÁN and JUAN S. MORA-SANGUINETTI: Quality of enforcement and investment decisions. Firm-level evidence from Spain.

1928 MARIO IZQUIERDO, ENRIQUE MORAL-BENITO and ELVIRA PRADES: Propagation of sector-specific shocks within Spain and other countries.

1929 MIGUEL CASARES, LUCA DEIDDA and JOSÉ E. GALDÓN-SÁNCHEZ: On financial frictions and firm market power.

1930 MICHAEL FUNKE, DANILO LEIVA-LEON and ANDREW TSANG: Mapping China's time-varying house price landscape.

1931 JORGE E. GALÁN and MATÍAS LAMAS: Beyond the LTV ratio: new macroprudential lessons from Spain.

1932 JACOPO TIMINI: Staying dry on Spanish wine: the rejection of the 1905 Spanish-Italian trade agreement.

1933 TERESA SASTRE and LAURA HERAS RECUERO: Domestic and foreign investment in advanced economies. The role of industry integration.

1934 DANILO LEIVA-LEON, JAIME MARTÍNEZ-MARTIIN and EVA ORTEGA: Exchange rate shocks and inflation comovement in the euro area.

1935 FEDERICO TAGLIATI: Child labor under cash and in-kind transfers: evidence from rural Mexico.

1936 ALBERTO FUERTES: External adjustment with a common currency: the case of the euro area.

1937 LAURA HERAS RECUERO and ROBERTO PASCUAL GONZÁLEZ: Economic growth, institutional quality and financial development in middle-income countries.

1938 SILVIA ALBRIZIO, SANGYUP CHOI, DAVIDE FURCERI and CHANSIK YOON: International Bank Lending Channel of Monetary Policy.

1939 MAR DELGADO-TÉLLEZ, ENRIQUE MORAL-BENITO and JAVIER J. PÉREZ: Outsourcing and public expenditure: an aggregate perspective with regional data.

1940 MYROSLAV PIDKUYKO: Heterogeneous spillovers of housing credit policy.

1941 LAURA ÁLVAREZ ROMÁN and MIGUEL GARCÍA-POSADA GÓMEZ: Modelling regional housing prices in Spain.

1942 STÉPHANE DÉES and ALESSANDRO GALESI: The Global Financial Cycle and US monetary policy in an interconnected world.

1943 ANDRÉS EROSA and BEATRIZ GONZÁLEZ: Taxation and the life cycle of firms.

1944 MARIO ALLOZA, JESÚS GONZALO and CARLOS SANZ: Dynamic effects of persistent shocks.

1945 PABLO DE ANDRÉS, RICARDO GIMENO and RUTH MATEOS DE CABO: The gender gap in bank credit access.

1946 IRMA ALONSO and LUIS MOLINA: The SHERLOC: an EWS-based index of vulnerability for emerging economies.

1947 GERGELY GANICS, BARBARA ROSSI and TATEVIK SEKHPOSYAN: From Fixed-event to Fixed-horizon Density Forecasts: Obtaining Measures of Multi-horizon Uncertainty from Survey Density Forecasts.

1948 GERGELY GANICS and FLORENS ODENDAHL: Bayesian VAR Forecasts, Survey Information and Structural Change in the Euro Area.

2001 JAVIER ANDRÉS, PABLO BURRIEL and WENYI SHEN: Debt sustainability and fiscal space in a heterogeneous Monetary Union: normal times vs the zero lower bound.

\section{BANCODEESPAÑA}

Eurosistema
Unidad de Servicios Auxiliares

Alcalá, 48 - 28014 Madrid

E-mail: publicaciones@bde.es www.bde.es 